Volume 3, Nomor 2, 2020, hlm. 193-220

P-ISSN: 2622-2280 | E-ISSN: 2622-4658

https://ejurnal.iiq.ac.id/index.php/alfanar

DOI: 10.33511/alfanar.v3n2.193-220

\title{
Ragam Kerusakan atas Perbuatan Manusia di Muka Bumi dalam Penafsiran Ibn Katsir
}

\author{
Nia Ariyani \\ UIN Syarif Hidayatullah Jakarta \\ nia.mumtaza1@gmail.com
}

\begin{abstract}
This research examines the various kinds of damage caused by human actions on earth. It should be explored. This is because the word damage or in Arabic is called fasād has different and varied implications. These impacts can be in the form of material damage impacts and non-material damage impacts. However, the object of interest is in humans. Humans on this earth are basically people who have a religion. This raises a question, why do people who have religion participate in the destruction? Religious people should actually take care and even repair them. This research uses descriptive-analytical. This is aimed at obtaining a comprehensive understanding of the various types of damage caused by human actions. The method used to collect the main data, namely verses related to damage with the keyword term fasād and its derivations using the book al-Mufrād fi Gharīb Al-Qur'ān. The data will then be analyzed using Ibn Katsir's interpretation which focuses on the bi al-Matsur method.
\end{abstract}

Keywords: Damage, Humans, Earth, Ibn Katsir.

\begin{abstract}
Abstrak
Penelitian ini mengupas tentang ragam kerusakan hasil perbuatan manusia di muka bumi kiranya patut ditelaah. Hal ini karena kata kerusakan atau dalam bahasa arab disebut fasād mempunyai dampak yang berbeda dan beragam. Dampak tersebut dapat berupa dampak kerusakan materi dan dampak kerusakan non-materi. Namun, yang menjadi objek menarik ada pada manusia. Manusia di muka bumi ini pada dasarnya adalah orang yang mempunyai agama. Hal ini menimbulkan sebuah pertanyaan, mengapa manusia yang mempunyai agama justru turut serta dalam kerusakan? Seharusnya orang yang beragama justru melakukan penjagaan dan bahkan per-baikan. Penelitian ini menggunakan deskriptif-analitis. Hal ini bertujuan agar mendapatkan pemahaman secara komprehensif mengenai ragam kerusakan hasil perbuatan manusia. Metode yang digunakan untuk mengumpulkan data utama, yaitu ayat-ayat yang terkait dengan kerusakan dengan kata kunci term fasād dan derivasinya menggunakan kitab alMufrād fì Gharīb Al-Qur'ān. Data-data tersebut kemudian akan dianalisis menggunakan penafsiran Ibn Katsir yang berfokus pada metode bi alMatsūr.
\end{abstract}

Kata Kunci: Kerusakan, Manusia, Muka Bumi, Ibn Katsir. 


\section{PENDAHULUAN}

Al-Qur'an merupakan sumber utama ajaran Islam yang di dalamnya terkandung ajaran Islam berupa akidah, syari'ah, dan akhlaq. Al-Qur'an juga sebagai pedoman untuk menghantarkan manusia kepada kebahagiaan. Untuk mencapai kebahagiaan tersebut manusia hendak mengamalkan dan memahaminya. ${ }^{1}$ Banyak pembahasan mengenai berbagai kehidupan di dalam Al-Qur'an, salah satunya pembahasan mengenai kerusakan hasil perbuatan manusia. Al-Qur'an juga sebagai pedoman umat manusia yang berisi petunjuk untuk memilih yang baik dan yang buruk.

Manusia diberikan potensi oleh Allah berupa potensi kebaikan dan potensi keburukan. Hal ini merupakan ujian yang hendak manusia lalui dengan mengontrol, mengawasi, dan memilih jalan yang telah diberikan petunjuknya di dalam kitab suci Al-Qur'an dan risalah para nabi. Jika potensi kebaikan manusia berjalan sebagaimana mestinya maka akan terjadi keseimbangan. Namun sebaliknya, jika potensi keburukan yang mendominasi maka akan terjadi ketimpangan yang berakibat pada kerusakan.

Kata, "kerusakan" di dalam Al-Qur'an menggunakan kata, "fasād.” Kementerian Agama RI dalam Tafsir Al-Qur'an Tematik yang berjudul, Pelestarian Lingkungan Hidup, bahwa di dalam Al-Qur'an term fasād dengan seluruh derivasinya (kata jadiannya) terulang sebanyak 50 kali. Sedangkan, di dalam kitab al-Mufrāt fì Gharīb Al-Qur'ān kata, "fasada" tertulis 10 kali yang berarti khurūj ash-shay' an al-i 'tidāl (sesuatu yang keluar dari keseimbangan). ${ }^{2}$

Dunia global saat ini sedang dihadapkan pada persoalan serius yang menentukan keberlangsungan hidup umat manusia, ${ }^{3}$ yakni: krisis spiritualitas, krisis kemanusiaan, dan krisis terhadap lingkungan hidup. Krisis spiritual, krisis kemanusiaan, dan krisis lingkungan hidup akan mengahantarkan manusia pada perbuatan kerusakan.

Alam yang diciptakan oleh Allah swt. terbentang luas untuk kehidupan manusia. Manusia yang diamanahkan peran sebagai khalīfah fi al-Ard (pemimpin di bumi), hendaknya menjalankan konsekuensi keimanannya dengan berhubungan baik kepada tiga hal, yaitu: Hubungan kepada Allah, hubungan kepada manusia, dan hubungan terhadap alam semesta. Manusia hendaknya bertanggungjawab untuk memelihara dan menjaga ketiga hal tersebut. Tanpa ada keseimbangan terhadap tiga hal tersebut, maka akan terjadi kerusakan dan ketidakseimbangan. Misalnya pada pemeliharaan alam yang meliputi: Tumbuh-tumbuhan, binatang-binatang, gunung-gunung, laut, air, dan sungai. Dalam peranannya sebagai khalifah, manusia hendak mengurus, memanfaatkan, dan memeliharanya. ${ }^{4}$ Namun faktanya manusia belum mampu mengemban amanah sebagai khalifah secara proporsional (seimbang).

Allah telah menciptakan alam semesta dengan seimbang. Allah berfirman di dalam

\footnotetext{
${ }^{1}$ Didin Saefuddin Buchori, Metodologi Studi Islam (Tangerang: Serat Alam Media, 2012), h. xi.

2 Abu Qosim al-Husain bin Muhammad, al-Mufrādat fì Gharīb Al-Qur'ān (Beirut: Darul Ma'rifah), h. 491.

${ }^{3}$ Agus Iswanto, "Relasi Manusia dengan Lingkungan dalam Al-Qur'an," Suhuf, vol. 6, no. 1 (2013), h. 1.

4 Departemen Agama RI, Pelestarian Lingkungan Hidup (Jakarta: Lajnah Pentashihan AlQur'an, 2009), h. 27.
}

194 I Al-Fanar: Jurnal Ilmu Al-Qur'an dan Tafsir 
Al-Qur'an surah al-Aḥqāf ayat 3:

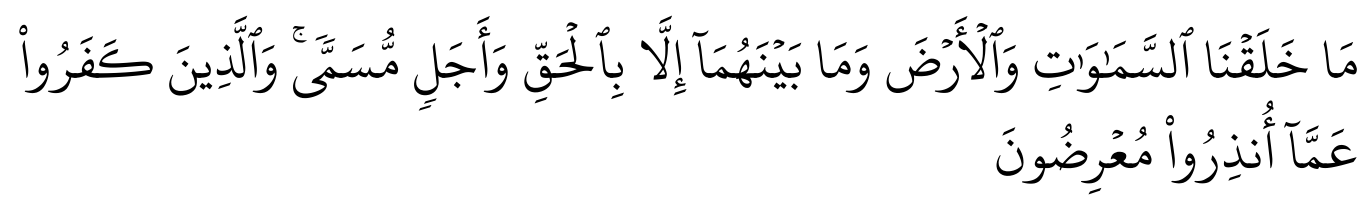

"Kami tidak menciptakan langit dan bumi dan apa yang ada diantara keduanya melainkan dengan tujuan yang benar dan dalam waktu yang ditentukan. Namun orang-orang kafir berpaling dari peringatan yang diberikan kepada mereka." (QS. al-Aḥqāf [35]: 3)

Keseimbangan antara makhluk hidup dan alam semesta berdampak pada keselarasan dan kesejahteraan hidup manusia. ${ }^{5}$ Begitu juga dengan keseimbangan manusia dengan Tuhan. Keseimbangan yang telah Allah berikan akan tetap terjaga bila manusia "tidak merusak" komponen alam semesta secara drastis.

Tauhid atau keimanan manusia yang seharusnya dapat dimanifestasikan dengan perilaku atau perbuatan baik. Namun faktanya kerusakan komponen alam semesta banyak terjadi karena perilaku manusia yang tidak bertanggungjawab. Misalnya: Kerusakan terhadap alam terjadi perilaku manusia yang membuang sampah sembarangan, penggunaan pestisida berlebihan, dan illegal logging (penebangan hutan) secara besarbesaran, dan kebakaran hutan secara luas. Allah berfirman di dalam Al-Qur'an surah ar-Raḥmān ayat 8-9:

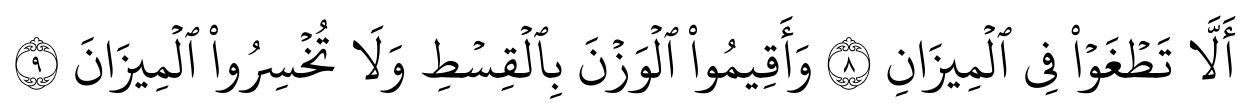

"Agar jangan kamu merusak keseimbangan itu, dan tegakkanlah keseimbangan itu dengan adil dan janganlah kamu mengurangi keseimbangan itu." (QS. arRaḥmān [55]: 8-9)

Al-Qur'an merupakan kitab hudā (petunjuk), kitab Furqān (pembeda antara kebenaran dan kebathilan), kitab adz-dzikr (pemberi peringatan) bagi ummat manusia. Implikasinya, berlaku pada siapa saja, Muslim atau non-Muslim. Ia mengahadirkan dirinya sebagai rahmat bagi seluruh ummat manusia. Konteks dari rahmat bagi seluruh ummat manusia ini, tidak ada jaminan bahwa orang yang mengaku Muslim pasti akan mendapat petunjuknya, dan tidak pula ada kepastian bahwa yang non-Muslim tidak memperoleh petunjuknya. ${ }^{6}$ Pembagian antara Muslim dan non-Muslim ini, menunjukkan tingkat kesadaran perilaku atau perbuatan manusia.

Menurut Ahzami Samiun Jazuli, Al-Qur'an merupakan pedoman hidup yang menyeru kepada manusia untuk berpikir logis, mempersiapkan diri sebaik-baiknya, mendayagunakan sarana yang ada, dan mengerahkan kemampuan guna dapat mengemban amanat tertinggi dimuka bumi, yaitu sebagai khalifah (pemimpin). ${ }^{7}$ Selain itu, menurut Efa Ida Amalia, Al-Qur'an merupakan sumber intelektualitas dan spiritualitas yang

\footnotetext{
${ }^{5}$ Ridwan Abdullah Sani, Sains Berbasis al-Qur'an (Jakarta: PT Bumi Aksara, 2015), h. 115.

${ }^{6}$ Kementerian Agama RI, Spriritualitas dan Akhlaq (Tafsir Al-Qur'an Tematik) (Jakarta: Lajnah Pentashihan Mushaf Al-Qur'an, 2010), h. 1.

${ }^{7}$ Ahzami Samiun Jazuli, Kehidupan dalam Pandangan Al-Qur'an, (Jakarta: Gema Insani, 2006), h. xi-xii.
} 
merupakan basis sumber inspirasi Muslim. ${ }^{8}$ Dalam hal ini dapat diidentifikasikan bahwa Al-Qur'an merupakan petunjuk bagi manusia secara komprehensif (menyeluruh). Baik itu sebagai pedoman hidup manusia dan juga sumber utama inspirasi pengetahuan.

Sebagai manusia yang bernotabane sebagai Khalifah fi al-Ardh yang tugasnya menjaga, mengatur, dan mengelola dan memakmurkan bumi adalah sebuah keniscayaan. Sebab yang membutuhkan bumi dan lingkungan bukanlah lingkungan itu sendiri. Namun, manusialah yang sangat membutuhkan lingkungan.

Alam yang terbentang luas di dalamnya terdapat beranekaragam jenis tumbuhan, jenis hewan, dan juga manusia yang hidupnya bertumpu terhadap alam, secara otomatis manusia akan memakan tumbuhan dan memburu jenis hewan dan bahkan memburu segala isi alam yang telah disediakan oleh Tuhan. Tumbuhan dan hewan akan hidup dengan sendirinya tanpa manusia. Tetapi sebaliknya, manusia tanpa tumbuh-tumbuhan dan hewan akan menyebabkan manusia tidak dapat memenuhi kebutuhan hidupnya. Di sinilah manusia disebut sebagai antroposentris.

Karena manusia disebut sebagai antroposentris yaitu manusia menempati pusat dari alam semesta, ${ }^{9}$ maka manusia hendaknya memperhatikan aturan-aturan yang ditetapkan Tuhan terhadap alam. Menjaga keseimbangan dengan tidak merusak. Tanpa memperhatikan aturan dan keseimbangan terhadap alam, maka akan terjadi masalah dan kerusakan. Allah berfirman di dalam Al-Qur'an surah ar-Rūm ayat 41-42:

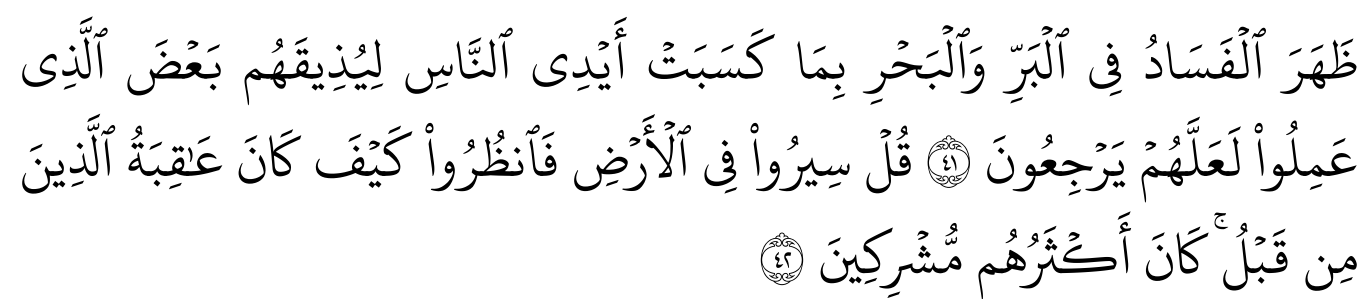

"Telah nampak kerusakan di darat dan di laut disebabkan karena perbuatan tangan manusia, supaya Allah merasakan kepada mereka sebagian dari (akibat) perbuatan mereka, agar mereka kembali (ke jalan yang benar). Katanlah: "Adakanlah perjalanan di muka bumi dan perhatikan bagaimana kesudahan orang-orang yang dahulu. Kebanyakan dari mereka itu orang-orang yang mempersekutukan (Allah).” (QS. surah ar-Rūm [30]: 41-42)

Menurut A. Sonny Keraf bahwa bencana atau kerusakan lingkungan terbagi menjadi dua bagian. Pertama, kerusakan atau bencana karena murni peristiwa alam, seperti: Gempa bumi, tsunami, dan gunung meletus. Kedua, kerusakan atau bencana karena krisis lingkungan hidup, akibat pola dari perilaku manusia, seperti: kehancuran, kerusakan, dan pencemaran lingkungan. ${ }^{10}$

Masalah kerusakan lingkungan pada dasarnya telah terjadi sejak zaman para Nabi. Syahrul Machmud menuliskan yang juga mengutip dari kitab-kitab suci baik agama 74.

${ }^{8}$ Efa Ida Amalia, “Kehancuran Alam Semesta dalam Al-Qur'an”. Suhuf, vol. 2, no. 1 (2009), h.

${ }^{9}$ A. Sonny Keraf, Etika Lingkungan Hidup, (Jakarta: PT Kompas Media Nusantara, 2010), h. 47.

${ }^{10}$ A. Sonny Keraf, Krisis dan Bencana Lingkungan Hidup Global, (Jogjakarta: Kanisius, 2010), h. 26 .

196 I Al-Fanar: Jurnal Ilmu Al-Qur'an dan Tafsir 
Islam, Kristen, dan Yahudi, Otto Soemarwoto yang seorang ahli ekologi, berpendapat, dengan menghubungkan kejadian yang dikisahkan dalam kitab suci berupa peristiwa air bah pada zaman Nabi Nuh dan berbagai kesulitan Nabi Musa di Gunung Pasir pada waktu pengembaraan dari Mesir ke Kana'an. ${ }^{11}$

Selain peristiwa di atas, peristiwa Nabi Yusuf dalam menafsir-kan mimpi raja (Mesir): "Aku melihat dalam mimpi tujuh ekor sapi betina yang tambun dimakan oleh tujuh ekor sapi yang kurus-kurus dan tujuh bulir gandum hijau dan tujuh lainnya kering." Nabi Yusuf menafsirkan terdapat dalam Al-Qur' an surah Yusuf ayat 47 yaitu: "Ia (Yusuf) berkata: "Selama tujuh tahun bertanam seperti biasa, dan hasil yang kamu tuai hanya bulir-bulirnya kecuali sebagian kecil yang kamu makan." Abdullah Yusuf Ali, menerangkan bahwa ayat ini mengisyaratkan langkah-langkah yang harus diambil dalam menghadapi bencana yang akan datang. Selama tujuh tahun akan ada hasil panen yang melimpah. Dari situ harus disediakan sedikit makanan yang disimpan bersama bulir-bulirnya, lebih baik lagi dilindungi dari hama yang menyerang gandum bila telah dibawa ketempat pengeringan. ${ }^{12}$

Peristiwa Nabi Nuh As dan Nabi Musa As di atas merupakan peristiwa bencana. Peristiwa Nabi Yusuf As di atas dapat mengambil hikmah mengenai antisipasi manusia untuk terus menjaga lingkungan agar tidak terjadi kerusakan.

Bencana dan kerusakan tentu bagian yang berbeda. Pada penelitian ini berpusat pada fas $\bar{a} d$ (kerusakan) bukan pada bencana. Perbedaan ini ditampilkan agar dapat memberikan informasi bahwa yang diteliti adalah kerusakan akibat perbuatan manusia.

Saat ini, telah memasuki era industrialisasi diberbagai belahan dunia, baik negara maju ataupun negara berkembang. Hingga keadaan yang digambarkan pada peristiwa nabi di atas sudah sangat berubah. Pembangunan manusia dalam memenuhi kebutuhan hidupnya telah mengubah cara pandang mengenai lingkungan.

Manusia membangun tapi manusia merusak. Seperti, manusia memakan jenis makanan; tanpa memperhatikan dimana manusia membuang bekas makanan. Manusia menebang hutan; tanpa memperhatikan pemanfaatan hingga terjadi penggundulan hutan. Manusia membangun industri tanpa memperhatikan lingkungan daratan, lautan, dan udara. Selain itu, yang paling penting penyebabnya adalah gaya hidup manusia modern yang tidak mengindahkan pedoman hidup, spiritualitas kepada Tuhan yang tidak dimanifestasikan dengan perbutan baik terhadap lingkungan. Akibatnya, kehancuran, kerusakan, polusi udara, dan pencemaran lingkungan darat dan air terus menjamur.

Sukidi, dalam bukunya, Teologi Inklusif Cak Nun, menuliskan bahwa pakar ekonomi pembangunan dunia, E. F. Schumacher, dalam bukunya, A Guide for the Per-Plaxed, 1981, memberitahukan bahwa krisis berangkat dari krisis spiritualitas dan krisis terhadap pengenalan diri terhadap yang absolut, yaitu Tuhan. ${ }^{13}$

Semua yang dituliskan di atas merupakan fasād (kerusakan). Namun fasād (kerusakan) ternyata terjadi akibat manusia tidak mengindahkan tauhidnya dengan h. 1 .

${ }^{11}$ Syahrul Machmud, Penegakan Hukum Lingkungan Indonesia, (Jogjakarta: Graha Ilmu, 2012),

${ }^{12}$ Abdullah Yusuf Ali, Tafsir Yusuf Ali, (Bogor: Pustaka Litera Antar Nusa, 2009), h. 557.

${ }^{13}$ Sukidi, Teologi Inklusif Cak Nun, (Jakarta: Kompas, 2001), h. 227. 
perbuatan baik. Tauhid memiliki konsekuensi terhadap manusia. Sebagaimana manusia telah mengikrarkan untuk bersaksi bahwa Tuhan yang disembah dan manusia juga bersaksi bahwa tidak ada Tuhan-Tuhan yang lain yang disembah. Konsekuensi tauhid diwujudkan dalam perbuatan baik.

Dari uraian di atas, maka penelitian ini berfokus pada bagaimana ragam kerusakan atas perbuatan manusia ditinjau dari pemikiran Ibn Katsir. Ada beberapa alasan dan pentingnya dalam penelitian ini, yaitu: pertama, salah satu permasalahan mengenai keseimbangan alam semesta ialah mengenai "kerusakan," yang di dalam Al-Qur'an disebut "fasād." Adapun salah satu persoalannya adalah kerusakan di muka bumi ini di lakukan oleh orang-orang beragama, tetapi minim pengetahuan terhadap yang absolut. Sebagaimana Sukidi dalam bukunya Teologi Inklusif Cak Nun yang juga mengutif E. F. Schumacher menuliskan bahwa krisis spiritualitas berangkat dari kurangnya pengenalan diri kepada Tuhan. Di sinilah muncul sebuah pertanyaan mengapa orang-orang yang beragama justru turut serta melakukan perbuatan kerusakan? Seharusnya, orang yang beragama pasti perbuatannya baik. Namun, faktanya kerusakan justru dilakukan oleh manusia yang beragama. Padahal jika manusia meyakini keimanannya maka akan terjadilah sebuah keseimbangan. Sehingga terciptalah harmonisasi keindahan, kepedulian, tidak merusak, dan tidak membiarkan kerusakan. ${ }^{14}$

Kedua, tema ini menjadi riset yang layak dilakukan karena term kerusakan di dalam Al-Qur'an jumlahnya sangat banyak derivasinya. Sehingga, sangat menarik untuk diteliti. Juga, perbuatan manuia menempati posisi yang erat kaitannya dengan mengapa terjadi kerusakan, sebagaimana Sonny A. Keraf menuliskan dalam bukunya, Etika Lingkungan Hidup, masalah lingkungan merupakan masalah perbuatan atau perilaku manusia.

Ketiga, mengapa penulis menggunakan Tafsir Ibn Katsir dalam penelitian ini, hal ini karena beberapa alasan: 1) Ibn Katsir atau yang bernama lengkap Imaduddin Abu al-Fida' Ismail bin al-Hafidz Abi Hufas Umar bin Katsir, ini merupakan 'ulama yang bermazhab Syafi'i, ${ }^{15}$ berakidah ahlusunnah wa al-Jama'ah. Ia terkenal juga sebagai tokoh panutan bergelar al-Hafidz. ${ }^{16}$ 2) Tafsir ini merupakan Tafsir Al-Qur'ān bi Al-Qur'ān, sebagaimana disebutkan bahwa metode penafsiran yang utama yaitu AlQur'an dengan Al-Qur'an. Jika tidak ada di dalam Al-Qur'an hendaknya menafsirkan dengan Hadis. Jika tidak menemukan di dalam Al-Qur'an dan hadis, maka hendaknya merujuk pada sahabat dan tabi'in. ${ }^{17}$ 3) Ibn Katsir dalam menjelaskan ayat-ayat mengenai kerusakan mengungkapkan sebagai akibat dari kemaksiatan manusia kepada Allah, sehingga menjadikan manusia lalai dan bahkan kufur kepada-Nya. Selain itu, kemaksiatan diakibatkan karena agama yang mengatur kehidupan manusia ternyata belum mampu termanifestasikan dengan perbuatan baik.

\footnotetext{
${ }^{14}$ Saifuddin Aman, Tren Spiritual Millenium Ketiga, (Jakarta: Ruhama, 2013), h. 59.

${ }^{15}$ Imaduddin Abu al-Fida' Ismail bin al-Hafidz Abi Hufas Umar bin Katsir, Tafsir Al-Qur'ān al- Adzìm, jilid 1 (Riyadh: Dar al-Salam, 1994), h. 18.

${ }^{16}$ Ibn Katsir, al-Bidāyah wa al-Nihāyah, terj. Abdullah bin Abdul Muhsin al-Turki, (Jakarta: Pustaka Azzam, 2013), h. 13.

${ }_{17}$ Abdullah bin Muhammad bin Abdurrahmad bin Ishaq Alu Syaikh, Tafsir Ibn Katsir Jilid 1 (Jakarta: Pustaka Imam Syafi'i, 2009), bagian Muqaddimah.
} 
Mengenai ayat-ayat fasād (kerusakan), penulis menelusuri kata Fasād dengan menggunakan kitab mufradāt (kosa kata) yaitu kitab al-Mufrād fì Gharīb Al-Qur'ān. Pada kitab ini, arti fasād (kerusakan) yang berarti "Sesuatu yang keluar dari keseimbangan," untuk diuraikan tafsirnya, yaitu: surah al-Baqarah [2] : 11, surah alBaqarah [2] : 12, surah al-Baqarah [2] : 220, surah al-Baqarah [2] : 205, surah Yūnus [10] : 81, surah al-Anbiyā' [21] : 22, surah al-Mu'minūn [23] : 71, surah al-Naml [27] : 34, surah al-Rūm [30] : 41-42.

\section{PROFIL IBN KATSIR}

Nama lengkap penulis kitab tafsir, Al-Qur'ān al-Adzìm (Tafsir Ibn Katsir) adalah Abu al-Fida' Imaduddin Ismail bin Umar bin Katsir al-Qurays al-Busyra. ${ }^{18}$ Ia lahir di daerah Mijdad, bagian dari Bushra, ${ }^{19}$ pada tahun $700 \mathrm{H}$ dan wafat pada tahun $774 \mathrm{H} .{ }^{20}$

Keluarga Ibn Katsir merupakan keluarga yang taat beragama. Hal ini ditandai dengan seorang ayah yang menjadi seorang 'ulama pada zamannya. Nama ayah Ibn Katsir adalah Syihab al-Din Abu Hafs 'Amr Ibn Katsir yang lahir pada $(640 \mathrm{H})$. Namun, sejak umur tujuh tahun, Ibn Katsir ditinggal oleh ayahnya yang meninggal dunia. Sehingga, ia dibesarkan oleh kakaknya, yaitu Kamal al-Din Abd Wahhab di Damaskus. $^{21}$

Ibn Katsir dalam kehidupannya sangat bersemangat menggali dan mendalami ilmu pengetahuan. Hal ini dapat dilihat ketika ia memulai pengembaraannya dan bertemu para 'ulama besar. Pertemuannya dengan para 'ulama menjadikan ia mendalami berbagai bidang ilmu, seperti: Tafsir, Hadis, Tarikh, dan Fiqh.

Dari semangatnya menggali dan mendalami berbagai ilmu di atas, jadi sangat wajar jika 'ulama setelahnya memberikan pujian kepadanya. Syaikh Manna al-Qathtan misalnya ia menuliskan bahwa Ibn Katsir merupakan seorang yang pakar fiqih yang mumpuni, ahli hadis yang cerdas, sejarawan yang ulung, dan mufassir yang unggul. Juga, Ibn Hajar berpendapat bahwa Ibnu Katsir seorang yang ahli dan hadis yang faqih. ${ }^{22}$

Ibn Katsir wafat pada 26 Sya'ban tahun $774 \mathrm{H}$. Makamnyaberdekatan dengan makam gurunya, yaitu Syaihul Islam Ibn Taymiah di pemakaman al-Shufiyah, kota Damaskus. ${ }^{23}$

\section{KARYA DAN PEMIKIRAN IBN KATSIR}

Ketekunan dan kegigihan Ibnu Katsir dalam mencari ilmu. Ia mendapat julukan alHafizd, yaitu para penjaganya Al-Qur'an. Selain al-Hafidz, ia juga menyandang gelar:

${ }^{18}$ Imaduddin Abu al-Fida' Ismail bin Katsir al-Qurays al-Busyra, Tafsir Al-Qur'ān al-Adzìm, jilid.1 (Riyadh: Dar as-Salam, 1994), h. 15.

${ }^{19}$ Bushra merupakan negeri di Syam dari bagian Damaskus.

${ }^{20}$ Abdullah bin Muhammad, Tafsir Ibn Katsir, Jakarta: Pustaka Imam asy-Syafi'i, 2008), h. xxv.

${ }^{21}$ Maliki, "Tafsir Ibn Katsir: Metode dan Bentuk Pemikirannya". el-Umdah, vol. 1, no. 1 (2018):, h. 76.

${ }^{22}$ Syaikh Manna al-Qaththan, Pengantar Studi Ilmu al-Qur'an (Jakarta: Pustaka al-Kautsar, 2005), h. 478.

${ }^{23}$ Imaduddin Abu al-Fida Ismail, Tafsir Juz 'Amma, terj. Farizal Tirmizi (Jakarta: Pustaka Azzam, 2007), h. xvii. 
al-Muhaddits, al-Faqih, al-Muarrik, dan al-Mufassir. ${ }^{24}$ Gelar tersebut yang diberikan di atas merupakan gelar karena berbagai karyanya yang fenomenal. Seperti kitab Ibn Katsir yang paling besar dan dipakai hingga saat ini adalah kitab Al-Qur'ān al-adzìm setelah kitab Tafsir al-Thabāri. Berikut ini sebagian karya-karya Ibn Katsir:

Pertama, Dalam bidang Tafsir, Ibn Katsir menulis dua kitab, yaitu: 1). Tafsir $\mathrm{Al}$ Qur'ān al-Adzìm, yaitu kitab tafsir 30 Juz yang menggunakan riwayat atau yang lebih terkenal dengan tafsir Al-Qur'ān bi al-Matsur, yaitu penafsiran Al-Qur'an dengan Al-Qur'an, atau dengan al-Sunnah karena menjelaskan kitabullah, atau riwayat yang diterima dari sahabat, atau dari riwayat Tabi'in. ${ }^{25}$ 2). Fada'il Al-Qur'ān, yaitu kitab yang berisi tentang ringkasan sejarah Al-Qur'an.

Kedua, Dalam bidang sejarah, Ibn Katsir menulis beberapa kitab, di antaranya: 1). al-Bidāyah wa al-Nihāyah (yang terdiri dari 14 jilid) yaitu sebuah kitab sejarah yang sangat fenomenal ,kitab ini berisi tentang cerita penciptaan alam semesta, cerita para Nabi umat terdahulu, cerita keadaan orang-orang jahiliyah, cerita tanda-tanda hari kiamat, tanda-tanda fitnah, dan hal-hal mengenai akhirat, 2). al-Fușul fì Shïrat al-Rasul yaitu kitab ini yang berisi uraian mengenai sejarah Rasul, 3). Thabaqat al-Syafi'iyyah, yaitu kitab yang berisi peringkat-peringkat ulama madzhab Syafi'i, 4). al-Kawakib alDarāri, yaitu kitab yang berisi cuplikan dari al-Bidāyah wa al-Nihāyah.

Ketiga, Dalam bidang hadis, Ibn Katsir menulis kitab, yaitu: 1). Jami'ul Masānid wa al-Sunan, yaitu kitab yang berisi kumpulan hadis. Di dalam kitab ini, Ibnu katsir menggabungkan antara Musnad Imam Ahmad, al-Bazzar, Abu Ya'la, Ibn Syaibah, dan al-Kutub al-Sittah, ${ }^{26}$ 2). Takhrij Ahadis Adillah al-Tanbih li 'Ulum al-Hadis, yaitu kitab takhrij terhadap hadis dalam kitab al-Tanbih karya al-Syirazi, (w. $476 \mathrm{H}$ ).

Keempat, Dalam bidang Fiqih, Ibn Katsir menulis kitab, yaitu: 1) Al-Ijtihad fi Thalab al-Jihad, yaitu kitab fiqih yang menjelaskan uraian untuk menggerakkan semangat juang ummat Islam dalam mempertahankan partai Lebanon-Suriah dari sebuah Frank dari Cyprus, 2) Al-Ahkam 'ala Abwab al-Tanbih, yaitu kitab yang berisi komentar terhadap al-Tanbih karya al-Syirazi.

\section{KONSEP PERBUATAN MANUSIA}

Manusia diberikan oleh Allah Subhanahuwata'ala sebuah potensi untuk melakukan sebuah perbuatan. Potensi tersebut dapat berupa potensi berbuat baik dan potensi berbuat buruk. Dengan kata lain, istilah dalam Al-Qur'an potensi itu dapat berupa kefasikan dan ketaqwaan. Hal ini terdapat di dalam Al-Qur'an pada surah al-Syams ayat 8:

${ }^{24}$ Muhaddits adalah gelar yang diberikan kepada orang yang ahli hadis dan berguru pada imamimamnya. al-Fiqih adalah gelar yang diberikan kepada orang yang ahli dalam bidang Fiqih. alMuarrik adalah gelar yang diberikan kepada orang yang ahli dalam bidang sejarah. Mufassir adalah gelar yang diberikan kepada orang yang ahli dalam bidang Tafsir.

${ }^{25}$ Mashruri Sirajuddin Iqbal dan Fudlali, Pengantar Ilmu Tafsir (Bandung: Percetakan Angkasa, 2009), h. 115.

${ }^{26}$ al-Hafizh Ibn Katsir, al-Bidāyah wa al-Nihāyah (Jakarta: Pustaka Azzam, 2013), h. 33. Dan ditahqiq oleh Abdullah bin Abdul Muhsin al-Turki.

200 | Al-Fanar: Jurnal Ilmu Al-Qur'an dan Tafsir 


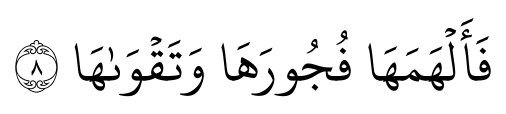

“Maka Dia mengilhamkan kepadanya (jalan) kejahatan dan ketaqwaan.” (QS. ash-Shams [91]: 8

Saryono ${ }^{27}$ menjelaskan bahwa manusia pasti mempunyai sifat-sifat baik dan sifatsifat buruk. Hal ini karena di dalam diri seseorang terdapat: a). Sudah ada kekuatan (memilih) untuk berbuat kejahatan dan keburukan (QS. ash-Shams [91]: 8), b). Sudah ada pendorong tersebut, yaitu malaikat dan setan. ${ }^{28}$

Perbuatan baik dan perbuatan buruk merupakan sifat yang bertentangan dan inilah ujian bagi manusia. Namun perlu diingat bahwa Allah menciptakan sifat yang bertentangan tersebut agar manusia menonjolkan sifat kebaikan. Sebagaimana fitrah manusia melakukan kebaikan.

Manusia yang mendapatkan ujian dari Allah hendaknya selalu belajar untuk selalu mengontrol diri dari perbuatan buruk. Karena apa saja kebaikan yang ada pada manusia adalah dari Allah dan apa saja keburukan yang ada pada diri manusia adalah berasal dari manusia itu sendiri. Hal ini telah diinformasikan di dalam Al-Qur'an surah al-Nisa ayat 79 , berikut:

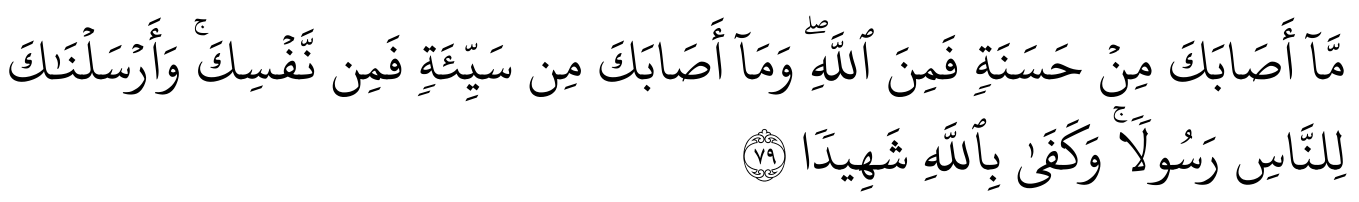

"Kabajikan apa pun yang kamu peroleh, adalah dari sisi Allah. Dan keburukan apa pun yang menimpamu, itu dari (kesalahan) dirimu sendiri. Kami mengutusmu (Muhammad) menjadi Rasul kepada (seluruh) manusia. Dan cukuplah Allah yang menjadi saksi.” (QS. an-Nisa' [4]: 79)

\section{TERM-TERM BAIK DAN BURUK DALAM AL-QUR'AN}

Al-Qur'an memberikan banyak pengertian mengenai term-term yang berkaitan dengan kebaikan dan keburukan. Seperti yang ditulis oleh Enoh dalam artikelnya Konsep Baik (Kebaikan) dan Buruk (Keburukan) dalam Al-Qur'an, term-term tersebut di antaranya adalah al-Hasanah dan al-Sayyi'ah, al-Khayr dan al-Syarr, alMa'ruf dan al-Munkar, al-Shālah dan al-Fāsid, al-Birr dan al-fähisyah, al-Khabīts dan al-Thayyib. ${ }^{29}$ Berikut ini penjelasannya:

\section{Al-Hasanah dan al-Sayyi'ah}

A.W. Munawwir dalam Kamus al-Munawwir Arab-Indonsesia Terlengkap, mengartikan al-Hasanah berarti memperindah dan membuat lebih bagus. ${ }^{30}$ Juga, al-Hasanah merupakan istilah yang digunakan untuk menggunakan kata baik. Sedangkan, al-

27 Saryono merupakan Mahasiswa Program Pascasarjana di Universitas Islam Negeri Raden Fatah Palembang.

${ }^{28}$ Saryono, “Konsep Fitrah dalam Persfektif Islam”. Studi Islam vol. 4, no. 2 (2016), h. 167.

${ }^{29}$ Enoh, "Konsep Baik (Kebaikan) dan Buruk (Keburukan) dalam al-Qur'an”. v. XXIII no. 1 (2007), h. 36 .

30 A.W. Munawwir, Kamus al-Munawwir Arab-Indonesia Terlengkap (Surabaya: Pustaka Progressif, 1997), h. 788. 
Sayyiah merupakan istilah yang dugunakan sesuatu yang dipandang tidak baik.

Menurut Abuddin Nata al-Hasanah misalnya: keuntungan, kelapangan rezeki, dan kemenangan. Sedangkan istilah al-Sayyi'ah misalnya: kesempitan, kelaparan, dan keterbelakangan. ${ }^{31}$ Allah berfirman di dalam Al-Qur'an surah ali-'Imran ayat 120 berikut:

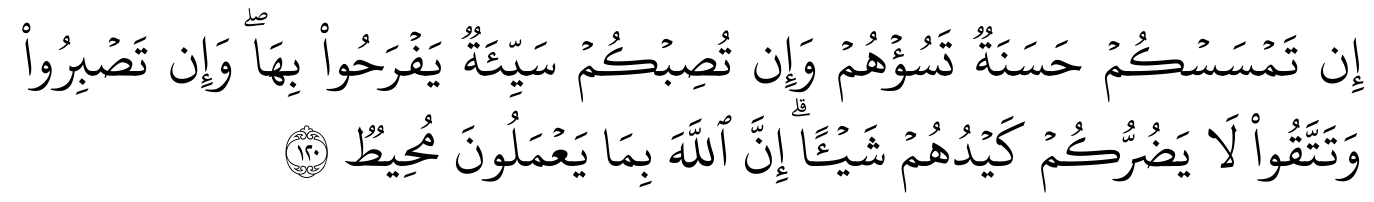

“Jika kamu memperoleh kebaikan, (niscaya) mereka bersedih hati, tetapi jika kamu tertimpa bencana, mereka bergembira karenanya. Jika kamu bersabar dan bertaqwa, tipu daya mereka tidak akan menyusahkan kamu sedikitpun. Sungguh, Allah maha meliputi segala apa yang kamu kerjakan.” (QS. Ali Imran [3]: 120)

Maksud dari kebaikan di sini adalah kebahagiaan, ke-menangan, dan kuatnya pendukung orang beriman, maka ketika melihat yang demikian itu orang munafik bersedih hati. ${ }^{32}$

Imam Sudarmoko mengartikan al-Sayyiah digunakan untuk sebuah kesempitan berupa siksaan. Siksaan itu dapat berupa peristiwa yang tidak menyenangkan dan dilakukan atas perbuatan buruk manusia yang bermaksiat kepada Allah. ${ }^{33}$ Allah berfirman:

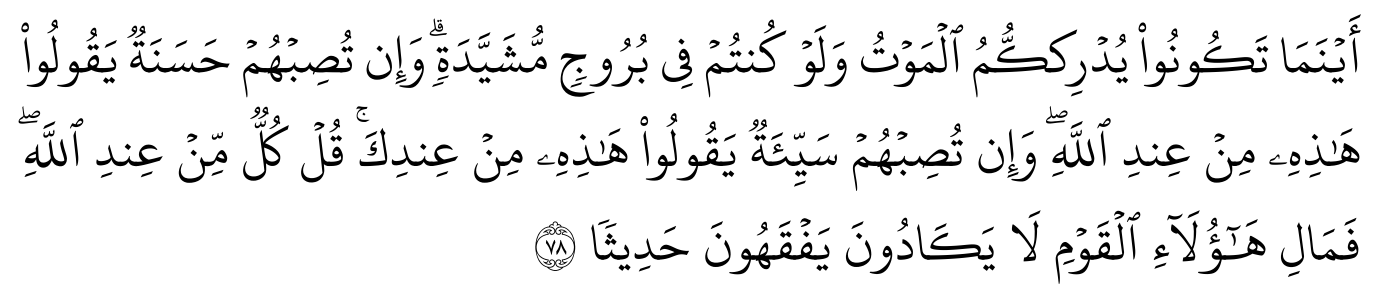

"Di mana pun kamu berada kematian akan mendapatimu, kendatipun kamu berada di dalam benteng yang tinggi dan kokoh. Jika mereka memperoleh kebaikan, mereka mengatakan, "Ini dari sisi Allah," dan jika mereka ditimpa suatu keburukan mereka mengatakan, "Ini dari engkau (Muhammad)." Katakanlah, "Semuanya (datang) dari sisi Allah." Maka mengapa orang-orang itu (orang-orang munafik-hampir tidak memehami pembicaraan (sedikit pun)?" (QS. an-Nisa' [4]: 78)

Dengan demikian dari berbagai pengertian dan ayat di atas penggunaan kata alHasanah dan al-Sayyi'ah mengarah pada akal dan tabiat manusia. Seperti halnya tabiat untuk mendapat nikmat berupa rezeki (makanan, nafkah), keuntungan, dan kelapangan. Dan sebaliknya, tidak ada tabiat manusia untuk mendapatkan kesusahan dan kesempitan rezeki.

\section{Al-Khayr dan al-Syarr}

Al-Khayr dalam bahasa Arab merupakan padanan kata yang paling dekat dengan istilah

\footnotetext{
${ }^{31}$ Abduddin Nata, Akhlak Tasawuf dan Karakter Mulia (Jakarta: Rajawali Pers, 2015), h. 101.

${ }^{32}$ Abdullah bin Muhammad bin Abdurrahman bin Ishaq Alu Syaikh, Tafsir Ibn Katsir, jilid, 7 (Jakarta: Pustaka Imam al-Syafi'i, 2009), h. 126.

${ }^{33}$ Imam Sudarmoko, “Keburukan dalam Persfektif al-Qur'an”. Dialogia, v. 12, no. 1 (2014): 24.
} 
"good," 34 atau istilah bahasa Indonesia biasa disebut dengan "kebaikan". Menurut Toshihiko Izutsu mengartikan istilah kata Khayr mengandung sesuatu yang bermanfaat, berguna, dan dapat diperlukan. ${ }^{35}$ Antonim (lawan kata) dari kata al-Khayr adalah alSyarr. Dalam Al-Qur'an al-Khayr dijelaskan seperti dalam sūrah Fussilat ayat 49-50.

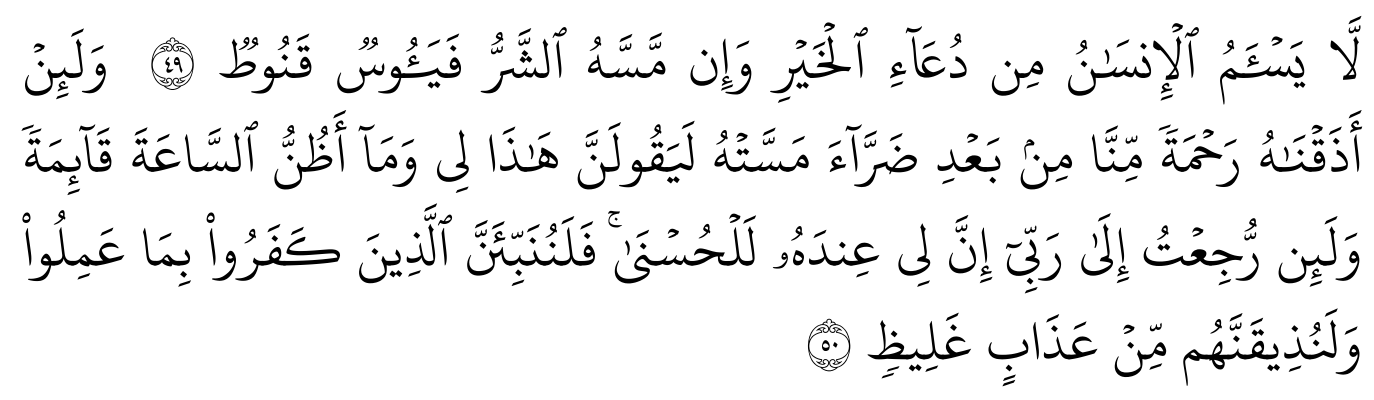

"Manusia tidak jemu memohon kebaikan, dan jika tertimpa malapetaka, mereka berputus asa dan hilang harapannya (49). Dan jika kami berikan kepadanya suatu rahmat dari kami setelah ditimpa kesusahan, pastilah dia berkata, "ini adalah hakku, dan aku tidak yakin bahwa dari kiamat itu akan terjadi. Dan jika aku dikembalikan kepada Tuhanku, sesuangguhnya aku akan mem-peroleh kebaikan disisi-Nya." Maka sungguh, akan kami beritahukan kepada orangorang kafir tentang apa yang telah mereka kerjakan, dan sungguh, akan kami timpakan kepada mereka azab yang berat (50)."

Al-Khayr di sini merupakan kebaikan harta dan keselamat-an. Sedangkan al-Syarr di sini merupakan keburukan yang berujung pada perbuatan manusia ketika diuji dengan kesempitan berupa kemiskinan akan kufur kepada Allah. Padahal Allah berfirman di dalam Al-Qur'an surah al-'Alaq ayat 6-7:

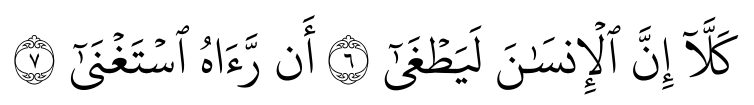

"Katahuilah! Sesungguhnya manusia benar-benar melampaui batas, karena dia melihat dirinya serba cukup.” (QS. al-“Alaq [96]: 6-7)

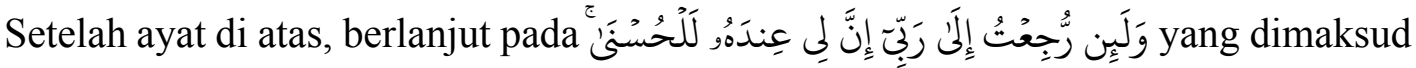
ayat ini merupakan jika di sana ada tempat kembali, maka Tuhan ku akan berbuat baik kepadaku sebagaimana Dia berbuat baik kepada ku di dunia. Dia berangan-angan kepada Allah, padahal amalnya buruk dan berada pada ketidakyakinan. ${ }^{r q}$ Hal itulah yang membuat Allah mengancam dengan siksaan dan hukuman.

Dari pengertian berbagai pengertian dan pemahaman di atas, maka al-Khayr dan al-Syarr mengarah pada kebaikan personal dan sosial berdasarkan komparasi. ${ }^{37}$ Komparasi antara kebaikan dan keburukan manusia dalam keyakinan terhadap sang pencipta. Ketika seluruh manusia meyakini akan kebesaran Allah yang memiliki segala apa yang ada di dunia, maka Allah akan memberikan kebaikan untuk Ummat.

${ }^{34}$ John M. Echols dan Hassan Shadily, Kamus Inggris Indonesia (Jakarta: PT. Gramedia Pustaka Utama, 2010), h. 275.

${ }^{35}$ Toshihiko Izutsu, Etika Beragama dalam al-Qur'an (Jakarta: Pustaka Firdaus, 1993), h. 335.

${ }^{36}$ Abdullah bin Muhammad bin Abdurrahman bin Ishaq Alu Syaikh, Tafsir Ibn Katsir, Jilid. 8 (Jakarta: Pustaka Imam asy-Syafi'i, 2009), h. 264-265.

${ }^{37}$ Enoh, "Konsep Baik (Kebaikan) dan Buruk (Keburukan) dalam Al-Qur'an,” v. XXIII no. (2007), h. 37. 


\section{Al-Ma'ruf dan al-Munkar}

Al-Ma'ruf berasal dari kata al-uruf yaitu sesuatu yang diketahui baik. Al-Munkar berasal dari kata al-nukr yaitu mencakup pengertian ingkar. ${ }^{38}$ Secara sederhana istilah al-Ma'ruf dan al-Munkar diartikan dengan kebaikan dan keburukan. Juga, kata al-Ma'ruf biasa digunakan untuk sebuah seruan yang baik. Sedangkan alMunkar biasa digunakan untuk sebuah seruan pencegahan dari kemungkaran. Dari kedua pengertian tersebut yang menjadi ukuran al-Ma'ruf dan al-Mungkar ada dua, yaitu: Agama dan akal sehat. ${ }^{39}$ Hal ini juga dapat dikatakan bahwa semua seruan yang diperintahkan agama adalah al-Ma' $r u f$ dan semua seruan yang dilarang agama adalah al-Munkar. Dengan demikian, penggunaan kata al-Ma' ruf dan al-Munkar mengarah pada kebaikan dan keburukan berdimensi hubungan vertikal kepada Tuhan, ${ }^{40}$ dan realisasinya adalah hubungan horizontal. Seperti terdapat di dalam Al-Qur'an surat Ali-Imran 104:

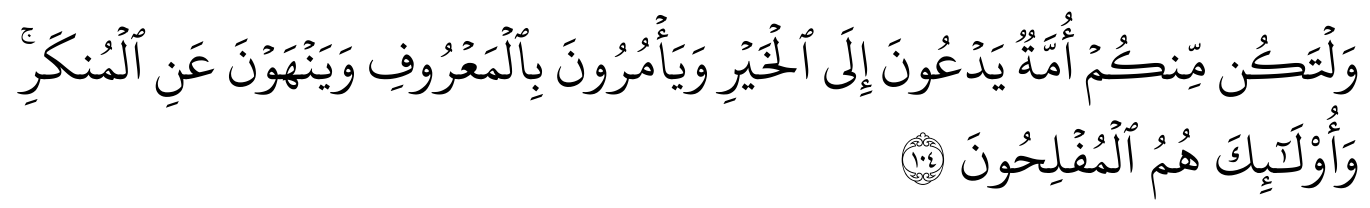

"Dan hendaklah diantara kamu ada segolongan orang yang menyeru kepada kebajikan, menyuruh (berbuat) yang ma'ruf, dan mencegah dari yang munkar. Dan mereka itulah orang-orang yang beruntung. " (QS. Ali Imran [3]: 104)

Selain pengertian di atas, Allah memerintahkan al-Ma 'rufdan al-Munkar hendaknya menggunakan cara-cara yang bijaksana, logis, dan pendekatan yang baik. ${ }^{41}$

\section{Al-Khabīts dan al-Thayyib}

Al-Khabits merupakan sebuah istilah yang menunjukkan keburukan. Sedangkan alThayyib adalah sebuah istilah yang menunjukkan kebaikan. Keburukan dan kebaikan yang dimaksud merupakan kata sifat yang melahirkan suatu pengertian rasa untuk berbagai peristiwa yang umum. Hal umum itu yang seringkali digunakan adalah menunjukkan sifat golongan, air, angin, wewangian, dan sebagainya. Misalnya penggunaan kata rīh thayyibah yaitu "Angin sepoi-sepoi" yang mendorong lajunya kapal dilautan dan penggunaan rīh asifah yaitu "Angin badai" (Yunus, 23). ${ }^{42}$ Selain itu, pengertian al-Khabits dan al-Thayyib yang menunjukkan pemisahan golongan terdapat di dalam Al-Qur'an surah al-Anfal ayat 37.

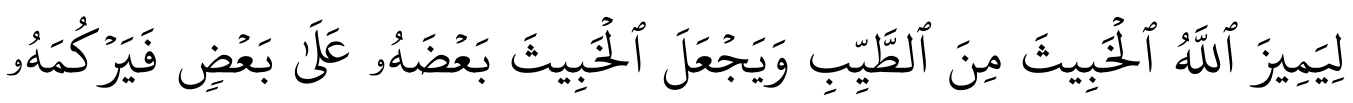

${ }^{38}$ Abdurrahman R.A. Haqqi dan Mohammad Nabil al-Munawwar, Tafsir Zanjabil (Jakarata: Qisthi Press, 2015), h. 114.

39 Yunahar Ilyas, Kuliah Akhlaq (Jogjakarta: Lembaga Pengkajian dan Pengamalan Islam (LPPI), 2001), h. 241.

${ }^{40}$ Enoh, “Konsep Baik (Kebaikan) dan Buruk (Keburukan) dalam al-Qur’an,” v. XXIII no. 1 (2007), h. 37.

${ }^{41}$ Muhammad Ali Hasyimi, Apakah Anda Berkepribadian Muslim? (Jakarta: Gema Insani Press, 1994), h. 107.

${ }^{42}$ Toshihiko Izutsu, Etika Beragama dalam al-Qur'an (Jakarta: Pustaka Firdaus, 1993), h. 386. 


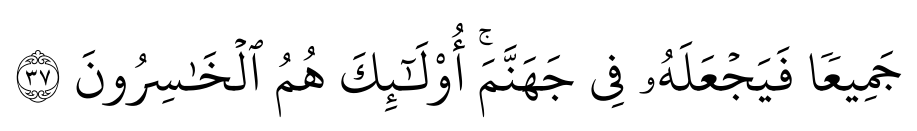

"Agar Allah memisahkan (golongan) yang buruk dari yang baik dan menjadikan (golongan) yang buruk itu sebagiannya di atas yang lain, lalu kesemuanya ditumpukkan-Nya, dan dimasukkan-Nya ke dalam neraka Jahanam. Mereka itulah orang-orang yang rugi."

\section{Al-Birr dan al-fähisyah}

Istilah al-Birr biasa digunakan upaya memperluas dan memperbanyak berbuat kebaikan. ${ }^{43}$ Izutsu mengemukakan bahwa al-Birr tidak mengarah dan memelihara hal-hal yang terlarang. Pembagian bentuk kata al-Birr yang demikian itu, seperti: a). al-Birr yang berarti bentuk taqwa kepada Allah (al-Baqarah, 185/ 189) dan (Ali'Imran, 86/92), b). al-Birr yang berarti taat kepada kedua orangtua (Maryam, 14), dan c). al-Birr yang berarti jujur dan adil dalam berperilaku (al-Mumtahanah, 8). Berikut contoh pengertian al-Birr dapat dilihat dalam Al-Qur'an surah al-Baqarah ayat 177 berikut:

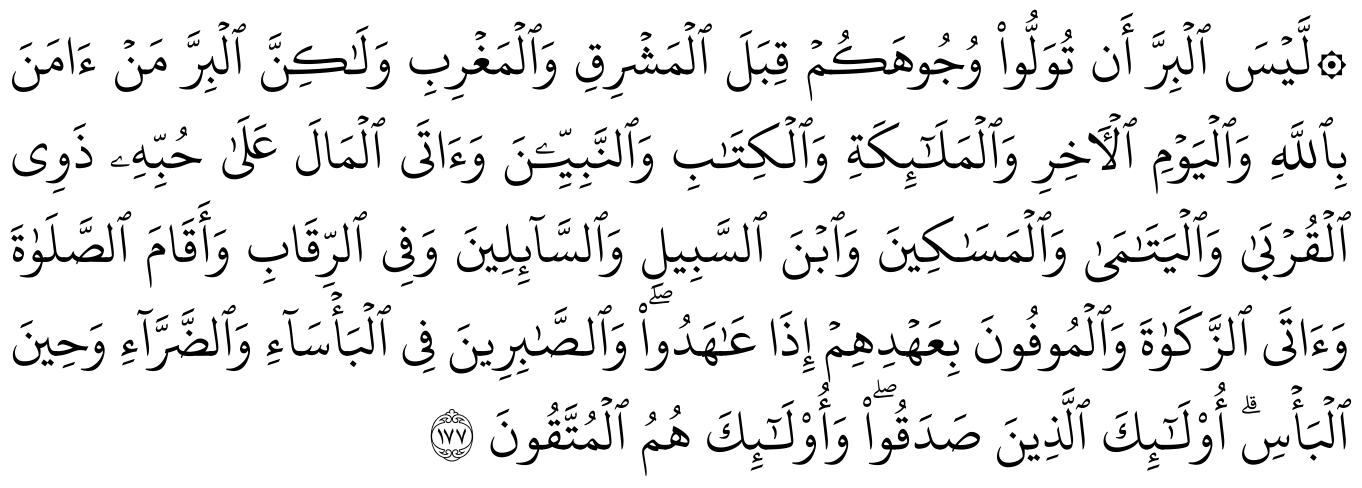

"Kebajikan itu bukanlah menghadapkan wajahmu ke arah timur dan ke barat, tetapi kebajikan itu ialah (kebajikan) orang yang beriman kepada Allah, hari akhir, Malaikat-malaikat, Kitab-kitab, dan Nabi-nabi dan memberikan harta yang dicintai kepada kerabat, anak yatim, orang-orang miskin, orang-orangyang dalam perjalanan (musafir), peminta-minta, dan untuk memerdekakan hamba sahaya, yang melaksanakan shalat dan menunaikan zakat, orang-orang yang menepati janji apabila berjanji, dan orang-orang yang sabar dalam kemelaratan, penderitaan dan pada masa peperangan. Mereka itulah orang-orang yang benar, dan mereka itulah orang-orang yang bertaqwa." (QS. al-Baqarah [2]: 177))

Al-fāhisyah dapat diartikan segala bentuk kecurangan dan keburukan yang melampaui batas. Atau bisa juga diartikan dengan perbuatan keji yang melampaui batas. ${ }^{44}$ Seperti perbuatan keji yang dilakukan pada masa Nabi Lut 'alaihissalam. Dengan demikian kata al-Birr dan al-fähisyah mengarah pada kebaikan yang bersifat hakiki dan keburukan yang bersifat hakiki pula. ${ }^{45}$ Hal ini dapat dilihat dalam Al-Qur'an pada surah al-'Araf ayat 80 berikut:

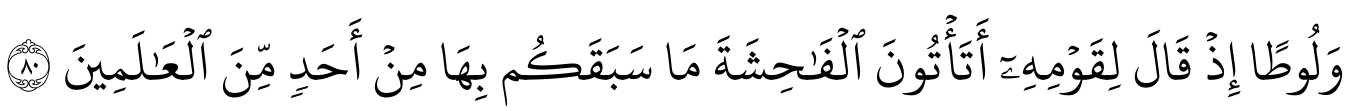

${ }^{43}$ Abduddin Nata, Akhlak Tasawuf dan Karakter Mulia (Jakarta: Rajawali Pers, 2015), h. 103.

${ }^{44}$ Imam Sudarmoko, “Keburukan dalam Persfektif al-Qur’an,” v. 12, no. 1 (2014): h, 26.

${ }^{45}$ Enoh, “Konsep Baik (Kebaikan) dan Buruk (Keburukan) dalam Al-Qur'an,” v. XXIII no. 1 (2007), h. 37. 
"Dan (Kami juga telah mengutus) Lut, ketika dia berkata kepada kaumnya,

"Mengapa kamu melakukan perbuatan keji, yang belum pernah dilakukan oleh seorang pun sebelum kamu (di dunia ini)." (QS. al-'Araf [7]: 80)

Menurut Teungku Muhammad Hasbi Ash-Shiddieqy penjelasan ayat di atas mengenai pengertian ayat "Sebelum kamu", menuliskan bahwa Ibn Katsir berpendapat maksudnya adalah tidak seorang pun dari Bani Adam yang mengerjakan perbuatan keji sebelum dilakukan oleh penduduk-penduduk Sodom. ${ }^{46}$

Kekejian atas perbuatan yang dilakukan oleh manusia pada zaman nabi Lut 'Alaihissalam merupakan kekejian yang bersifat melampaui batas (di luar fitrah manusia). Sebagaimana kita ketahui bahwa sejarah kaum Sodom telah melakukan perbuatan buruk. Keburukan yang dilakukan berupa keinginan manusia melakukan perbuatan biologis, seperti: Laki-laki menyukai sesama laki-laki. Padahal itu merupakan perbuatan yang di larang Allah.

\section{Al-Shälih dan al-Fäsid}

Ahmad Warson Munawwir menuliskan dalam, Kamus al-Munawwir Arab-Indonesia, bahwa al-Shālih berasal dari kata shalaha yang berarti baik dan bagus. ${ }^{47}$ Sedangkan al-Fāsid merupakan keburukan.

Pada dasarnya Al-Qur'an menggunakan term al-Shälih dan al-Fāsid lebih cenderung berhubungan dengan kebaikan dan keburukan secara umum dan menunjukkan kebaikan bersifat fitrah, bersifat alamiah, dan atau bersifat sebagaimana seharusnya menurut ketentuan Allah. Misalnya: Ketika Allah melarang untuk tidak melakukan kerusakan di muka bumi, maka bentuk fitrah manusia sebagai hamba adalah menjalankan perintahNya untuk tidak merusak bumi. Allah berfirman di dalam Al-Qur'an surah al-'Araf ayat 56:

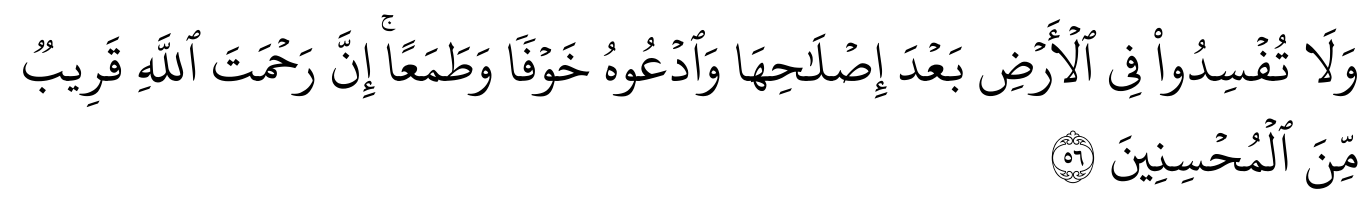

"Dan janganlah kamu berbuat kerusakan di bumi setelah (diciptakan) dengan baik. Berdo'alah kepada-Nya dengan rasa takut dan penuh harap. Sesungguhnya rahmat Allah sangat dekat kepada orang yang berbuat kebaikan.” (QS. al-A'raf [7]: 56)

Ayat di atas memberikan pengertian "Janganlah kamu merusak bumi" merupakan pencegahan berbuat syirik dan maksiat setelah adanya istilah perbaikan melalui tauhid dan kataatan. ${ }^{48}$ Perbaikan yang dimaksud tentunya akan banyak menempuh berbagai cara, diantaranya: Menyeru dan memerintahkan manusia bertauhid, melarang menyekutukan Allah, dan menjelaskan akibat positif dan negatif dari konsekuensi tauhid. ${ }^{49}$ Seperti

46 Teungku Muhammad Hasbi Ash- Shiddieqy, al-Bayan Tafsir Penjelas Al-Qur'anul Karim (Semarang: Pustaka Rizki Putra, 2002), h. 364.

47 Ahmad Warson Munawwir, Kamus al-Munawwir Arab-Indonesia (Surabaya: Pustaka Progressif, 1997), h. 788.

${ }^{48}$ Syaikh Abu Bakar Jabir al-Jazairi, Tafsir al-Qur'an al-Aisar (Jakarta: Darus Sunnah, 2015), h. 78 .

49 Abd. Rahman Dahlan, Kaidah-kaidah Penafsiran al-Qur'an (Bandung: Penerbit Mizan, 1998), h. 210. 
halnya ketika Allah melarang melakukan kerusakan di muka bumi akan ada hal positif yang mengikutinya, begitupun sebaliknya.

Konsekuensi tauhid seseorang akan membawa pada manusia menjalankan perintah Allah dan menjauhi segala yang dilarang Allah. Dia melarang kerusakan agar tidak mem-bahayakan manusia, ${ }^{50}$ inilah bukti kekuasaan-Nya. Allah ber-firman pada ayat selanjutnya, Al-Qur'an surah al-'Araf ayat 57:

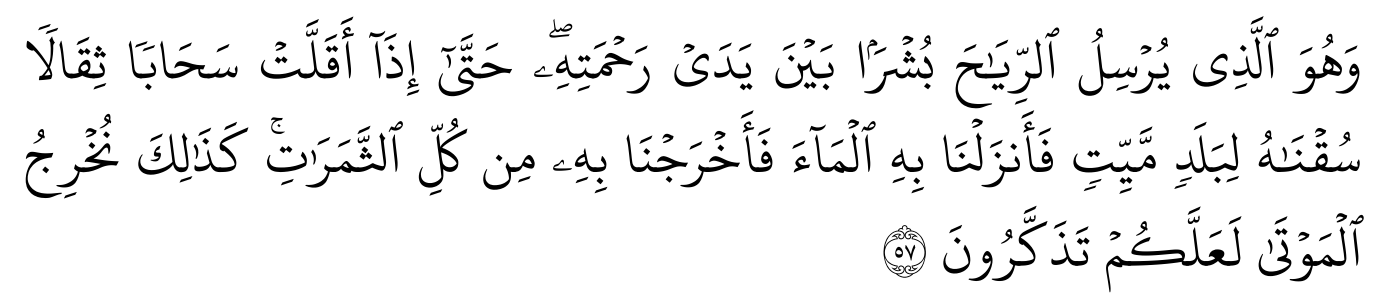

"Dialah yang meniupkan angin sebagai pembawa kabar gembira, medahului kedatangan rahmat-Nya (hujan) sehingga apabila angin itu membawa awan mendung, kami halau ke suatu daerah yang tandus, lalu kami turunkan hujan di daerah itu. Kemudian kami tumbuhkan dengan hujan itu berbagai macam buahbuahan. Seperti itulah kami membangkitkan orang yang telah mati, mudahmudahan kamu mengambil pelajaran." (QS. al-A'raf [7]: 57)

\section{ANALISIS AYAT-AYAT KERUSAKAN DI MUKA BUMI}

Sebelum menjelaskan ayat-ayat mengenai kerusakan di muka bumi, terlebih dahulu penulis menyampaikan pengertian mengenai fasād (kerusakan).

Al-Ashfahani dalam kitabnya al-Mufradāt fì Gharīb Al-Qur'ān menjelaskan arti kata fas $\bar{a} d$ sebagai berikut:

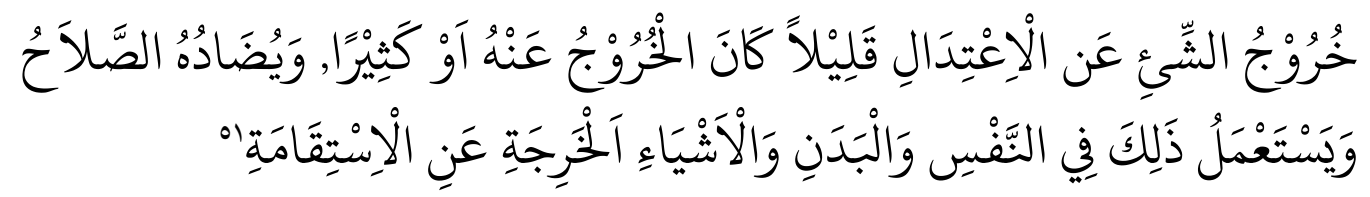

"Keluarnya sesuatu dari kondisi normal baik keluarnya sedikit ataupun keluarnya banyak, lawannya adalah shālah. Kata fasād digunakan untuk jiwa, badan, dan segala sesuatu yang keluar dalam kondisi baik (istiqomah)."

Sesuatu yang keluar dari keseimbangan merupakan perbuatan yang sangat merusak tatanan kehidupan. Misalnya saja keseimbangan yang objeknya jiwa dan badan manusia. Jiwa manusia membutuhkan asupan berupa spiritual (rohani) dan asupan jasmani. Ketika manusia memberikan kebutuhan hanya kepada salah satu anggota saja, maka akan terjadi stres atau pun sakit. Pengembangan daya jasmani tanpa dibarengi daya rohani akan membuat seseorang pincang, berat sebelah, dan kehilangan keseimbangan. ${ }^{52}$ Begitu juga terhadap hak-hak (perintah atau larangan) yang telah Allah tetapkan di dalam Al-Qur'an. Sebagaimana Al-Qur'an sebagai pembeda dan berisi ayat-

${ }^{50}$ Abdullah bin Muhammad bin Abdurrahman bin Ishaq Alu Syaikh, Tafsir Ibn Katsir, jilid, 3 (Jakarta: Pustaka Imam asy-Syafi'i, 2009), h. 390.

${ }^{51}$ Abu Qosim al-Husain bin Muhammad, al-Mufradāt fì Gharīb al-Qur'ān, (Beirut: Dar alMa'rifah), 491 pada www.dialogilmu.com/ 205/ 11/ kitab-al-mufrada-fi-gharib-al-qur'an-karya-alashfahani. Html?m=1

${ }^{52}$ Moh. Ardani, Ahklaq-Tasawuf (Penerbit: CV. Karya Mulia, 2005), h. 1. 
ayat tanzīliyah yang berfungsi sebagai petunjuk bagi manusia baik hubungan dengan Allah, hubungan dengan manusia, dan hubungan dengan alam semesta. Siapa yang mengamalkannya akan diberi pahala, siapa yang memutuskan hukum berdasarkan AlQur'an akan adil, dan siapa yang menyerukan Al-Qur'an akan dibimbing ke jalan yang lurus. ${ }^{53}$ Tanpa manusia menjalankan hak-hak Allah dengan baik, maka akan terjadi kekacauan, kerusakan dan ketidakseimbangan.

Pada dasarnya segala sesuatu di dunia ini diciptakan oleh Allah dengan baik. Maksud baik di sini adalah segala yang diciptakan oleh Allah berpasangan, proporsional, dan berbeda. Perbedaan apa yang ada di bumi menjadikan alam ini seimbang. Keseimbangan inilah yang hendak dijaga, dilestarikan, dan dibudayakan. Namun pada kenyataannya, manusia yang hidup di muka bumi tidak selamanya memahami bagaimana menjadikan alam ini tetap dalam kondisi baik dan keseimbangan. Di sinilah perbutan manusia akan menentukan bagaimana keseimbangan itu akan terjaga.

Perbuatan manusia adalah segala sesuatu yang timbul dari dalam diri atas dasar kesadaran, pertimbangan, dan pilihan. Manusia berhak menentukan perbuatannya (Perbuatan baik dan perbuatan buruk). Jika manusia tidak dapat menjaga akidahnya, maka akan rusaklah akidahnya. Jika manusia melakukan perbuatan kemaksiatan, maka menyimpanglah perbuatannya. Dan, jika manusia memilih jalan untuk merusak bumi maka akan rusaklah bumi dan seisinya. Dari pernyaaan itulah dapat diiasumsikan bahwa kerusakan timbul dari akibat perbuatan manusia yang dilakukan dengan sengaja. Sehingga membawa pada dampak negatif. Setidaknya ada dua dampak negatif, yaitu: a). Kerusakan dalam bentuk materi, b). Kerusakan dalam bentuk non-materi.

Untuk mendapatkan pemahaman mengenai analisis ayat-ayat kerusakan di muka bumi, berikut penjelasannya:

\section{Kerusakan Akibat Penyimpangan Akidah}

Akidah adalah tonggak atau dasar dari sebuah keyakinan seorang hamba kepada Allah. Juga, akidah adalah denyut nadi keberagamaan dan kehidupan seorang Muslim. ${ }^{54}$ Menurut Ali Abdul Halim Mahmud dalam bukunya, Akhlaq Mulia, mengatakan bahwa akidah seorang akan benar dan lurus jika kepercayaan dan keyakinannya lurus dan benar. ${ }^{55}$ Dasar perbuatan baik bagi seorang Muslim adalah Akidah. Akidah diibaratkan sebagai akar yang kuat dari sebuah pohon. Seorang yang memiliki akidah yang kuat maka akan membawa manusia pada ibadah yang baik yang baik diwujudkan dengan perbuatan baik. Tanpa akidah manusia akan kehilangan tujuan dalam hidupnya. Akidah juga akan menjadi baik bila manusia tidak menyekutukan, menduakan, atau mempercayai adanya kekuat-an dari benda-benda yang ada di alam semesta.

Manusia yang fitrahnya adalah berakidah hendaknya mengindahkan apa yang telah menjadi keyakinan kepada Allah. Apabila manusia tidak mengindahkan keyakinannya maka akan terjadi ketidakseimbangan yang menyebabkan kerusakan. Kerusakan dalam

${ }^{53}$ Sa'id Abdil Adzim, Berimanlah Sejenak Pasti Anda Selamat (Jakarta: Kalam Mulia, 2006), h. 9 .

${ }^{54}$ Syahrin Harahap dan Hasan Bakti Nasution, Ensiklopedia Akidah Islam (Jakarta: Kencana, 2009), dalam kata pengantar.

${ }^{55}$ Ali Abdul Halim Mahmud, Akhlaq Mulia (Jakarta: Gema Insani Press, 2004), h. 84. 
bentuk akidah, misalnya me-nyekutukan Allah dengan mendatangi tukang tenung dan tukang sihir. Manusia mengira bahwa hal ini hanya merupakan jalan menuju Allah, padahal inilah yang dinamakan dengan perbuatan menyekutukan Allah. Berikut ayat yang menjelask-an tentang penyimpangan akidah.

1. Surah Yunus [10]: 81

Di dalam kitab Al-Qur'ān al Adzìm, Ibn Hatim berkata: "Bercerita kepadaku Muhammad bin 'Ammar al-Harits, bercerita kepadaku 'Abdurrahman, yakni alDasytaki, Abu Ja'far ar-Razi memberi kabar kepadaku, bahwa sesungguhnya ayat-ayat itu adalah obat sihir dengan izin Allah, kamu membacanya dalam bejana berisi air kemudian disiramkan di atas kepala orang yang terkena sihir, ${ }^{56}$ ayat yang ada pada surat Yunus berikut ini:

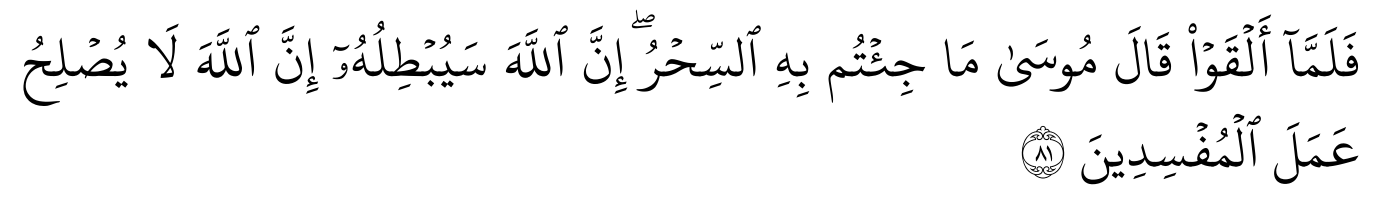

"Setelah mereka melemparkan, Musa berkata, "Apa yang kamu lakukan itu, itulah sihir, sesungguhnya Allah akan menampakkan kepalsuan sihir itu. Sungguh, Allah tidak akan membiarkan terus berlangsungnya pekerjaan orang yang berbuat kerusakan." (QS. Yunus [10]: 81)

Kisah tukang-tukang sihir yang dilakukan pada masa nabi Musa telah berlalu. Perbuatan orang-orang terdahulu mengenai sihir dilemahkan dengan datangnya peringatan nabi Musa terhadap kaumnya. Sebenarnya yang menjadi tujuan dari ayat ini adalah untuk menunjukkan pembangkangan Fir'aun terhadap ajakan Rasul Allah. ${ }^{57}$

Penjelasan mengenai perbuatan dalam hal penyimpangan akidah tidak hanya terbatas pada surat Yunus di atas, mengingat bahwa tafsir Ibn Katsir ini menggunakan metode $b \bar{\imath}$ al-Ma'tsūr, maka ayat ini berhubungan dengan surah al-'araf : 118-122 dan surah Tha'ha: 69 berikut:

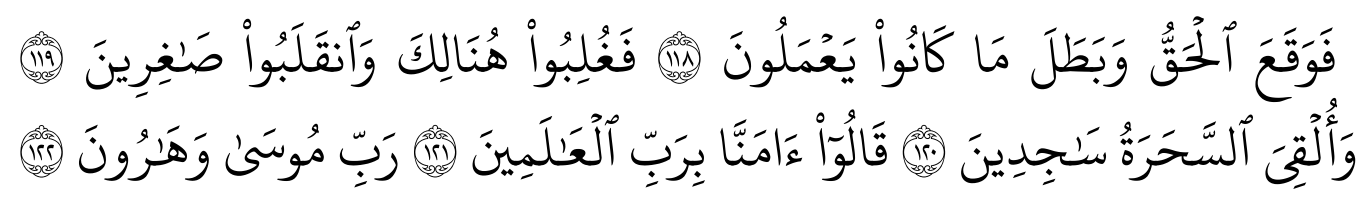

"Maka terbuktilah kebenaran, dan segala yang mereka kerjakan sia-sia, maka mereka dikalahkan di tempat itu dan jadilah mereka orang-orang yang hina, dan para pesihir itu serta merta menjatuhkan diri dengan bersujud, mereka berkata, "Kami beriman kepada Tuhan selain alam, (yaitu) Tuhannya Musa dan Harun." (QS. al-A'raf [7]: 122)

Pada ayat ini Ibn Abbas berkata: Tongkat Musa tidaklah melewati tali-tali dan tongkat-tongkat mereka itu melainkan ditelannya. Kemudian pada akhirnya para ahli sihir itu mengetahui bahwa hal itu merupakan sesuatu yang datang dari langit dan bukan sihir. Maka mereka bersujud dan mengatakan, "Kami beriman kepada Rabb,

${ }^{56}$ Imaduddin Abu al-Fida' Ismail bin Umar bin Katsir, Tafsir al-Qur'ān al-Adzīm, jilid, 3 (Riyadh: Dar al-Salam, 1994), h. 562.

${ }^{57}$ M. Quraish Shihab, Tafsir al-Misbah (Jakarta: Lentera Hati, 2004), h. 135. 
yaitu Rabb Musa dan Harun." 58 Kemudian ayat di atas berkaitan atau berlanjut pada Al-Qur'an surah Thaha: 69:

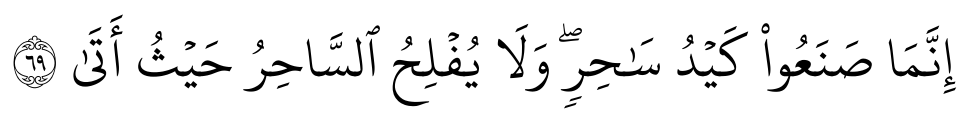

"Apa yang mereka buat itu hanyalah tipu daya pesihir (belaka). Dan tidak akan menang pesihir itu, dari mana pun ia datang." (QS. Thaha [20]: 69)

Dari paparan ayat-ayat di atas dapat disimpulkan bahwa, penyimpangan akidah sebenarnya telah dilakukan oleh kaum terdahulu, yaitu kaumnya Nabi Musa 'Alaissalam. Perbuatan sihir menyebabkan akidah manusia menyimpang. Sehingga dengan hadirnya ayat ini mengingatkan kepada kita semua untuk berhati-hati dalam menjaga akidah.

2. Surah al-Anbiya [21]: 22

Allah berfirman di dalam surah al-Anbiya berikut:

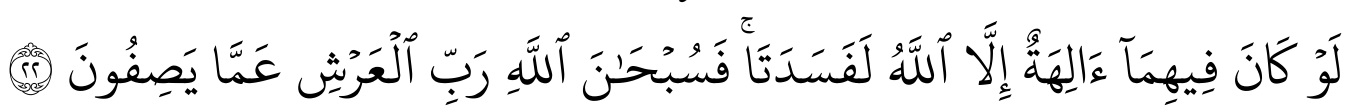

"Seandainya pada keduanya (di langit dan di bumi) ada Tuhan-tuhan selain Allah, tentu keduanya telah binasa. Maha suci Allah yang memiliki 'Arsy, dari apa yang mereka sifatkan.” (QS. al-Anbiya [21] : 22)

Ayat ini menjelaskan bahwa kerusakan langit dan bumi di-akibatkan karena manusia menyekutukan Allah. Allah mengabarkan jika terdapat Tuhan-tuhan yang lain selain-Nya, niscaya rusaklah langit dan bumi. ${ }^{59}$ Selain itu di dalam tafsir al-Thabāri juga dijelaskan maksud Al-Qur'an surat al-Anbiya di atas adalah sekiranya di langit dan bumi ada Tuhan yang patut disembah selain Allah, maka akan rusak dan binasa. ${ }^{60}$ Hal ini terdapat dalam Al-Qur'an surah al-Mu’Minūn ayat 91 berikut:

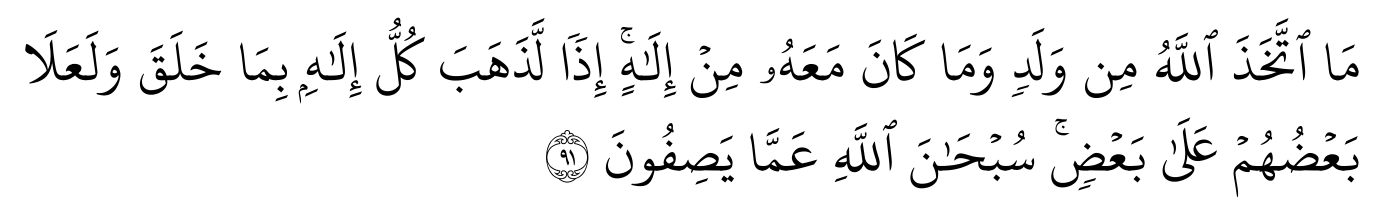

"Allah tidak mempunyai anak, dan tidak ada tidak ada Tuhan (yang lain) bersama-Nya, (sekiranya Tuhan banyak), maka masing-masing Tuhan itu akan membawa apa (makhluk) yang diciptakan, dan sebagian dari Tuhan-Tuhan itu akan mengalahkan sebagian yang lain. Mahasuci Allah dari apa yang mereka sifatkan itu." (QS. al-Mu'Minūn [23]: 91)

Selain pada ayat di atas Allah menjelaskan di dalam Al-Qur'an bahwa Allah itu satu dan tidak ada Tuhan selain-Nya. Hal ini terdapat di dalam Al-Qur'an surah alIkhlas berikut:
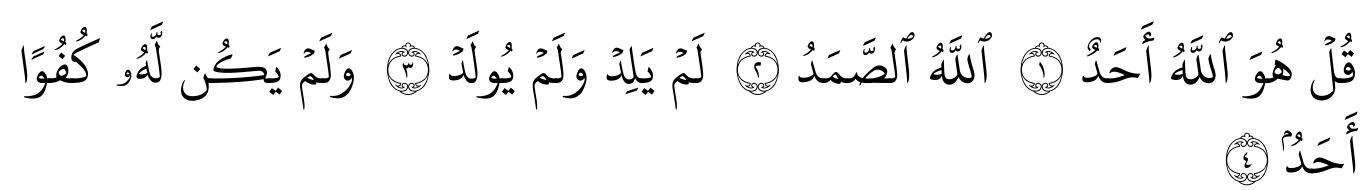

\footnotetext{
${ }^{58}$ Abdullah bin Muhammad bin Abdurrahman bin Ishaq Alu Syaikh, Tafsir Ibn Katsir, jilid 3 (Jakarta: Pustaka Imam asy-Syafi'i, 2009), h. 431.

${ }^{59}$ Abdullah bin Muhammad bin Abdurrahman bin Ishaq Alu Syaikh, Tafsir Ibnu Katsir, jilid 6 (Jakarta: Pustaka Imam asy-Syafi'i, 2009), h. 75.

${ }^{60}$ Abu Ja'far Muhammad bin Jarir al-Thabari, Tafsir al-Thabāri, terj. Ahsan Askan (Jakarta: Pustaka Azzam, 2009), h. 43.
} 
"Katakanlah (Muhammad), "Dialah Allah, Yang Maha Esa. Allah tempat meminta segala sesuatu. (Allah) tidak beranak dan tidak pula diperanakkan.

Dan tidak ada sesuatu yang setara dengan Dia.” (QS. al-Ikhlas [112]: 1-4)

Penjelasan mengenai akidah sangat banyak di dalam Al-Qur'an. Sejarah mencatat Rasulullah menyebarkan akidah selama 13 tahun. Hal ini dikarenakan sangat pentingnya akidah menjadi pedoman utama dalam kehidupan. Tanpa akidah kehidupan akan goyah, dan sebaliknya dengan akidah kehidupan akan kuat dan tertata.

Dengan demikian, kerusakan dalam bentuk akidah dapat berupa menyekutukan Allah dengan mendatangi tukang tenung dan tukang sihir. Dalam hal ini dapat dikategorikan bahwa kerusakan ini berupa kerusakan non-materi. Kerusakan non-materi adalah kerusakan yang berdampak pada seseorang yang melakukan penyimpangan terhadap akidah atau keyakinan kepada Allah.

\section{Kerusakan Akibat Kemaksiatan}

Kemaksiatan merupakan perbuatan yang dilakukan manusia yang melanggar perintah Allah. Kemaksiatan juga dapat diartikan sebagai perbuatan manusia yang buruk. Manusia yang mempunyai potensi untuk melakukan sesuatu (perbuatan baik atau buruk) dapat mengarahkan "keinginan" sesuai dengan "kehendak" pada diri sendiri. Misalnya: Ketika Allah melarang "Janganlah merusak bumi” maka perintah itu terdapat dua potensi manusia yang dapat dilakukan, yaitu "Melanggar" atau "Menaati".

Merusak bumi merupakan bagian dari perbuatan yang sangat merusak tatatanan ekosistem bumi. Pada dasarnya bumi memang diciptakan untuk manusia. Di dalam bumi terdapat tumbuhan dan hewan untuk kebutuhan manusia. Namun apabila kebutuhan manusia tersebut tidak diimbangi dengan proporsional, maka akan terjadi kerusakan. Kerusakan dalam arti kemaksiatan terdapat pada: surah al-Baqarah (2) : 11, h surahBaqarah [2]: 12, dan surah al-Baqarah [2]: 205.

1. Surah al-Baqarah [2]: 11

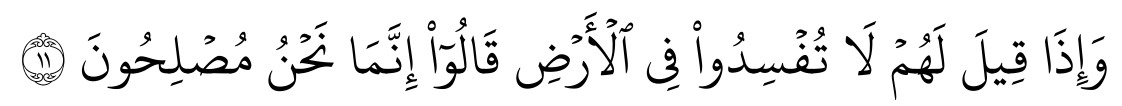

"Dan apabila dikatakan kepada mereka, "Janganlah membuat kerusakan di bumi!" Mereka menjawab, Sesungguhnya kami justru orang-orang yang melakukan perbaikan." (QS. al-Baqarah [2] : 11)

Di dalam tafsir Al-Qur'ān al-Adzìm, Ibn Mas'ud dan sahabat nabi menjelaskan bahwa yang di maksud pada ayat ini adalah:

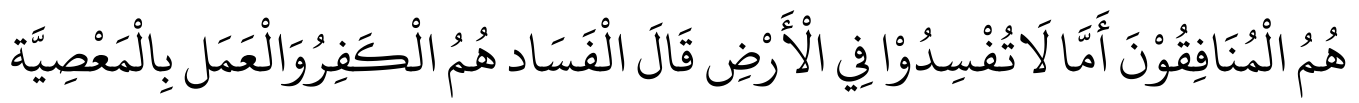

"Mereka adalah orang munafik. Sedangkan "kerusakan” di muka bumi yang dimaksud adalah kekufuran dan perbuatan kemaksiatan."

Kata fasād (kerusakan) di atas menginformasikan kepada kita bahwa kerusakan di sini bukan hanya kerusakan pada umumnya, seperti kerusakan pada benda atau pun alam semesta. Melainkan, kerusakan di sini akibat dari perbuatan manusia yang menyimpang, seperti: menghasut orang-orang kafir untuk memusuhi dan menentang 
orang-orang Islam. ${ }^{61}$

Kemaksiatan seseorang akan menyebabkan manusia keluar dari keimanan. ${ }^{62} \mathrm{Abu}$ Ja'far menceritakan, dari al-Rabi' bin Anas, dari Abul 'Aliyah, ia mengatakan janganlah kalian berbuat kerusakan di muka bumi. "Kerusakan ini berupa ke-maksiatan kepada Allah, karena barang siapa yang berbuat maksiat kepada Allah atau memerintahkan orang lain untuk bermaksiat kepada-Nya, maka ia telah berbuat kerusakan di bumi, karena kemaslahatan langit dan bumi ini terletak pada ketaatan." ${ }^{63}$

Selain itu, Qurays Shihab menjelaskan bahwa seseorang dituntut untuk menjadi shaleh, yaitu memelihara segala sesuatu yang ada di bumi sehingga kondisinya tetap baik dan tetap bermanfaat. ${ }^{64}$ Namun, orang-rang munafik menduga bahwa mereka mencapai peringkat ini. Inilah yang menjadi permasalahan bahwa kemunafikan dilakukan oleh orang-orang yang merasa bahwa dirinya telah beriman.

2. Surah al-Baqarah [2] : 12

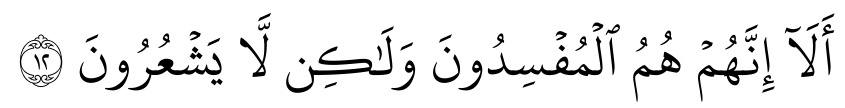

"Ingatlah, sesungguhnya merekalah yang berbuat kerusakan, tetapi mereka tidak menyadari.” (QS. al-Baqarah [2]: 12)

Dalam tafsir Ibn Katsir, melalui ayat tersebut Allah memberitahukan: "Ketahuilah bahwa yang mereka katakan sebagai perbaikan adalah kerusakan itu sendiri, namun karena kebodohan mereka, mereka tidak menyadari bahwa hal itu sebagai kerusakan." 65 Kerusakan pada ayat ini dilakukan atas dasar perbuatan yang dilakukan berulangulang. Kerusakan di sini bermakna pengrusakan kepada keluarga, masyarakat, dan bahkan bumi. ${ }^{66}$ Sehingga membawa pada perbuatan yang menanamkan kebencian dan perpecahan.

Abu Ja'far berkata, ayat ini merupakan bentuk pendustaan Allah atas apa yang dilakukan oleh orang-orang munafik, ketika Allah memerintahkan seharusnya mereka menaati dan ketika Allah melarang sesuatu seharusnya mereka menjauhi. ${ }^{67}$

Menurut Kamus Besar Bahasa Indonesia (KBBI), kata munafik berarti berpura-pura atau mengatakan sesuatu yang tidak sesuai perbuatannya, inilah sebuah pendustaan. Pada masalah ini sebuah pendustaan termasuk pada kategori kerusakan non-materi. Kerusakan non-materi ini berdampak pada perbuatan manusia yang menjatuhkan pada kemaksiatan kepada Allah.

${ }^{61}$ Kementerian Agama RI, Pelestarian Lingkungan Hidup (Jakarta: Direktorat Urusan Agama Islam, 2012), h. 211.

${ }^{62}$ Imam Jalaluddin al-Mahalli dan Imam Jalaluddin al-Suyuthi, Tafsir Jalalain, terj. Bahrun Abubakar (Bandung: Sinar Baru Algensindo, 2009), h. 7.

${ }^{63}$ Imaduddin Abu al-Fida Ismail bin Katsir al-Qurays al-Dimasqy, Tafsir al-Qur'ān al-Adzīm, jilid 1 (Riyadh: Dar al-Salam, 1994), h. 79.

${ }^{64}$ M. Qurays Shihab, Tafsir al-Misbah (Tangerang: Lentera Hati, 2000), h. 101.

${ }^{65}$ Imaduddin Abu al-Fida Ismail bin Katsir al-Qurays al-Dimasqy, jilid 1 (Riyadh: Dar al-Salam, 1994), h. 79.

${ }^{66}$ M. Qurays Shihab, Tafsir al-Misbah (Tangerang: Lentera Hati, 2000), h. 102.

${ }^{67}$ Abu Ja'far Muhammad bin Jarir al-Thabari, Tafsir al-Thabari, terj. Abdul Somad, Yusuf Hamdani, dkk (Jakarta: Pustaka Azzam, 2008), h. 358. 
3. Surah al-Baqarah [2]: 205

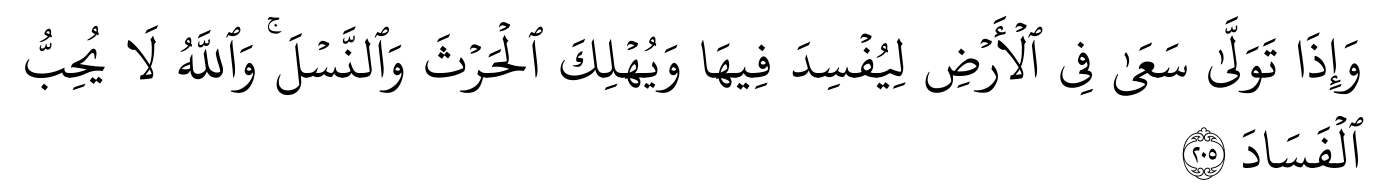

"Dan apabila dia berpaling (dari engkau), dia berusaha untuk berbuat kerusakan di bumi, serta merusak tanam-tanaman dan ternak, sedang Allah tidak menyukai kerusakan." (QS. al-Baqarah [2]: 205)

Kata, tawalla di sini merupakan berasal dari kata wilāyat yang berarti pemerintahan. Ketika orang munafik mengontrol pe-merintahan maka mereka mulai membuat kerusakan, kejahatan, penindasan, dan juga kedzaliman. ${ }^{68}$ Kedzaliman itu dapat berupa perbuatan yang menyebabkan masyarakat dan kota-kota akan hancur dan bahkan nyawa akan terancam bahaya.

Selain itu, ayat di atas maksudnya adalah orang yang amat menyimpang perkataannya dan jahat perbuatannya. Seperti itulah perkataan dan perbuatannya. Ucapannya dusta, keyakinannya menyimpang dan perbuatnnya buruk. ${ }^{69}$ Orang yang mempunyai "keinginan" membuat kerusakan di bumi dan memusnahkan tanamantanaman dan hewan-hewan. Maka, Mujahid mengatakan, "Maka Allah akan menahan hujan sehingga tanaman dan ternak binasa." 70

\section{Kerusakan Akibat Penyimpangan Memperlakukan Orang yang Lemah (Anak Yatim)}

Yatim merupakan orang yang telah ditinggal oleh ayahnya. Dalam konteks agama dan kemanusiaan, seseorang yang telah ditinggal oleh ayahnya berhak untuk mendapatkan perhatian dan perlakuan yang baik. Perhatian itu dapat berupa sandang, pangan, dan bahkan papan. Namun yang menjadi permasalahan adalah ketika orang yang lemah diabaikan, memberikan (sandang dan pangan) yang tidak sepantasnya, dan bahkan ikut serta memakan harta anak yatim secara dzalim. Padahal di dalam Al-Qur'an terdapat surat yang memerintahkan untuk memperdulikan, memberikan makanan yang layak, dan tidak memakan harta anak yatim.

Perbuatan manusia yang tidak seimbang dalam mem-perlakukan orang yang lemah akan menyebabkan kerusakan. Sebagaimana kerusakan dalam arti penyimpangan memperlakukan orang yang lemah (anak yatim) terdapat dalam Al-Qur'an surah alBaqarah [2]: 220

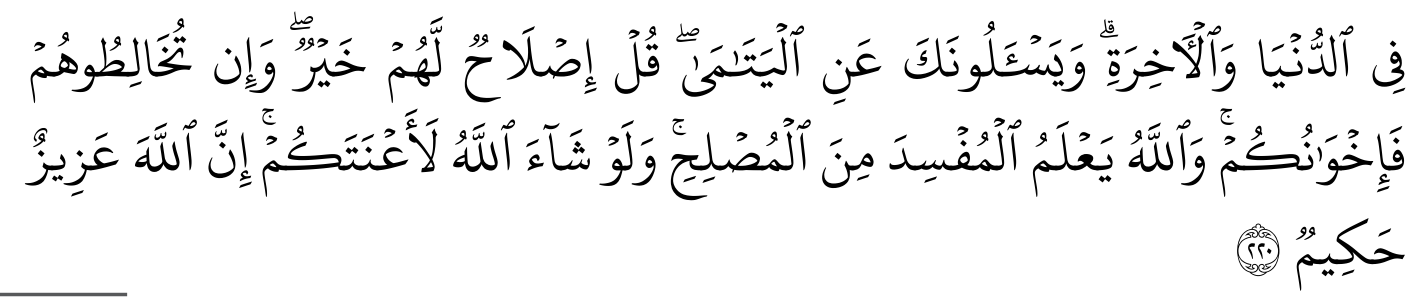

${ }^{68}$ Allamah Kamal Faqih Imani, Tafsir Nurul Qur'an, terj. Rd Hikmat Danaatmaja (Jakarta: alHuda, 2003), h. 156.

${ }^{69}$ Imaduddin Abu al-Fida Ismail bin Katsir al-Qurays al-Dimasqy, Tafsir al-Qur'ān al-Adzīm, jilid 1 (Riyadh: Dar al-Salam, 1994), h. 333.

${ }^{70}$ Abdullah bin Muhammad bin Abdurrahman bin Ishaq Alu Syaikh, Tafsir Ibn Katsir, jilid 1 (Jakarta: Pustaka Imam asy-Syafi'i, 2009), h. 403. 
"Tentang dunia dan akhirat. Mereka menanyakan kepadamu (Muhammad) tentang anak-anak yatim. Katakanlah, "Mem-perbaiki keadaan mereka adalah baik!" Dan jika kamu mem-pergauli mereka, maka mereka adalah saudarasaudaramu. Allah mengetahui orang yang berbuat kerusakan dan yang berbuat kebaikan. Dan jika Allah menghendaki, niscaya Dia datangkan kesulitan kepadamu. Sungguh, Allah Mahaperkasa, Maha-bijaksana.” (QS. al-Baqarah [2] : 220)

Di dalam tafsir Ibn Katsir, bahwa Ibn Jarir meriwayatkan dari Ibn 'Abbas, ia menceritakan, ketika turun dalam Al-Qur'an surah al-An'am [6] yang artinya "Dan janganlah kamu mendekati harta anak yatim kecuali melalui cara yang lebih baik." Dan dalam Al-Qur'an surah al-Nisa' [4] : 10

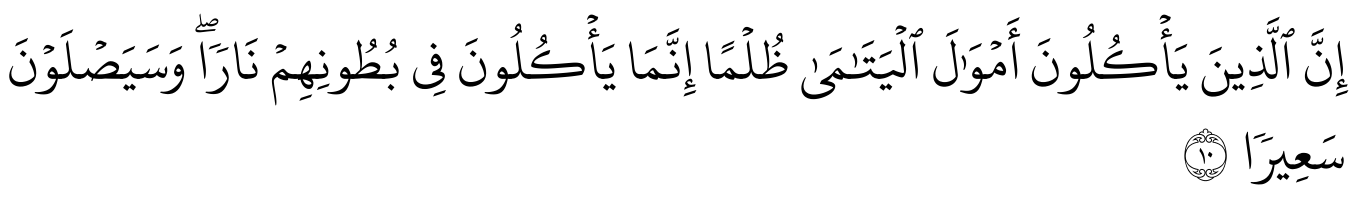

"Sesungguhnya orang-orang yang memakan harta anak yatim secara dzalim, sebenarnya mereka telah menelan api dalam perutnya dan mereka akan masuk ke dalam api yang menyala-nyala (neraka)." (QS. al-Nisa' [4] : 10)

Dengan turunnya ayat ini, orang yang mengasuh anak yatim langsung memisahkan makanan dan minuman anak yang yang diasuhnya. Lalu memisahkan sebagian dari makanannya dan ia simpan untuk anak yatim, sampai anak yatim memakannya atau menjadi basi. Karena itu menyulitkan pengasuh anak yatim, lalu mereka melaporkan kepada Rasulullah Shallallahu 'alaihi wasallam. Maka Allah menurunkan ayat:

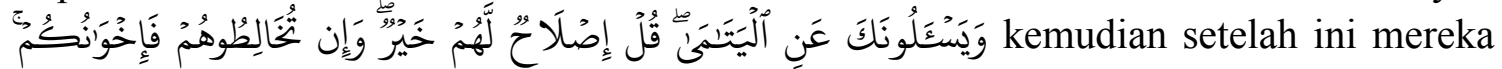
menggabungkan makanan dan minuman mereka dengan makanan dan minuman anak yatim.

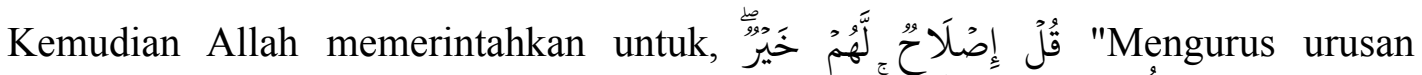

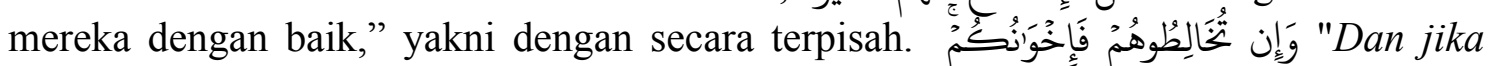
kamu menggauli mereka, maka mereka adalah saudaramu," maksudnya adalah boleh menggabungkan makanan dan minuman kalian dengan makanan dan minuman mereka,

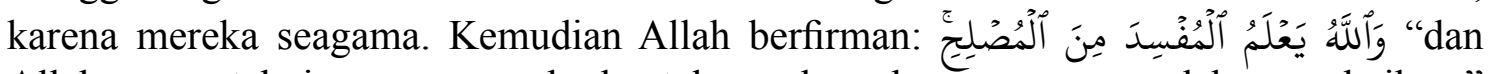
Allah mengetahui orang yang berbuat kerusakan dan yang mengadakan perbaikan," yang berarti, Dia mengetahui orang yang berniat memberbuat kerusakan dari orang yang berniat melakukan perbaikan. ${ }^{71}$

Dari uraian di atas memberikan pengertian bahwa perbuatan buruk yang sangat merusak seperti: Memperlakukan ayak yatim dengan cara tidak memperdulikan, tidak berbuat baik, dan bahkan menghardiknya adalah perbuatan merusak. Juga, seperti disebutkan dalam buku, Pelestarian Lingkungan Hidup, demikian kata mufsid pada ayat ini merupakan kebalikan dari muslih yaitu orang yang tidak peduli terhadap nasib anak yatim. ${ }^{72}$ Di sinilah letak sifat perbuatan orang-orang yang mendustakan agama. Padahal Allah telah berfirman di dalam surat al-Ma'un 1-7 berikut:

\footnotetext{
${ }^{71}$ Abdullah bin Muhammad bin Abdurrahman bin Ishaq Alu Syaikh, Tafsir Ibn Katsir, jilid 1 (Jakarta: Pustaka Imam asy-Syafi'i, 2009), h. 425-426.

72 Departemen Agama RI, Pelestarian Lingkungan Hidup (Jakarta: Lajnah Pentashihan alQur'an, 2009), h. 214.
} 


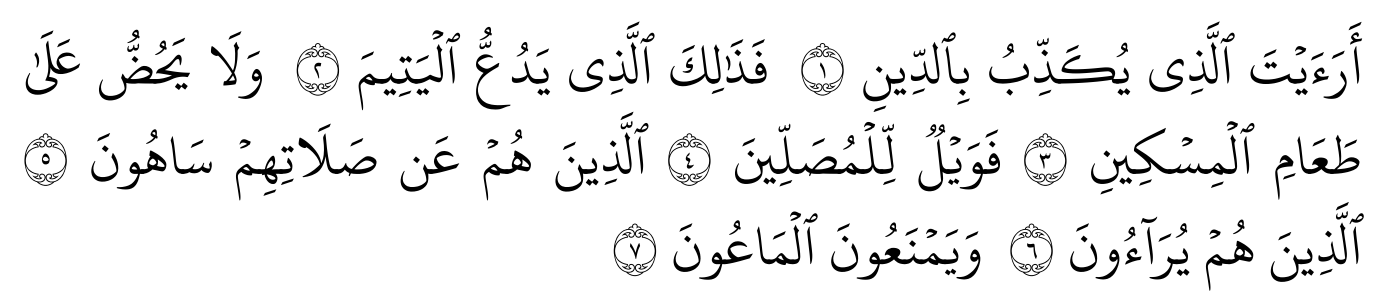

"Tahukah kamu (orang) yang mendustakan agama?, maka itulah orang yang menghardik anak yatim, dan tidak mendorong memberi makan anak miskin, maka celakalah orang yang shalat, (yaitu) orang yang lalai terhadap shalatnya, yang berbuat ria, dan enggan (memberikan) bantuan." (QS. al-Ma'un [107]: $1-7)$

Dalam surat al-Ma'un di atas menimbulkan sebuah pertanyaan apakah orang yang melakukan shalat mengaku sebagai orang yang beragama? Dari pertanyaan tersebut dapat dikatakan bahwa ternyata shalat saja belum cukup, apabila manusia yang beragama masih mengahambakan diri pada hawa nafsu mencibtai harta secara berlebihan dan tidak perduli terhadap anak yatim. ${ }^{73}$

\section{Kerusakan Akibat Memperturutkan Hawa Nafsu}

Allah memberikan manusia potensi berupa hawa nafsu. Hawa nafsu merupakan sebuah potensi untuk menentukan pilihan, sebagaimana fungsi dari hawa nafsu adalah untuk manusia menjalankan kehidupan sebagaimana fitrahnya. Misalnya: Ketika manusia ingin memenuhuhi kebutuhan fisiknya dengan makan, maka manusia diberikan untuk memilih makan seperlunya atau makan berlebihan. Bila manusia memilih untuk makan berlebihan, maka akan timbul berbagai macam penyakit yang dapat membuat manusia sakit. Begitu juga dengan prilaku manusia dalam mengerjakan perintah dan larangan Allah. Bila manusia melakukan larangan makan akan terjadi kerusakan. Kerusakan dalam arti "Memperturutkan hawa nafsu" terdapat dalam surah al-Mu'minun [23] : 71 dan Surah al-Naml [27] : 34.

1. Surah al-Mu'minun [23] : 71

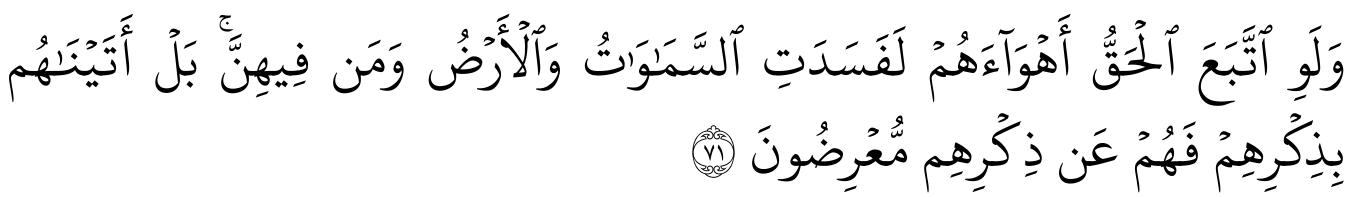

"Dan seandainya kebenaran itu menuruti keinginan mereka, pasti binasalah langit dan bumi, dan semua yang ada di dalamnya. Bahkan kami telah memberikan peringatan kepada mereka, tetapi mereka berpaling dari peringatan itu." (QS. al-Mu'minun [23] : 71)

Dalam Tafsir Ibn Katsir, Mujahid dan Abu Shalih serta al-Suddi mengatakan: Hak itu adalah Allah yang Mahamulia lagi Mahaperkasa. Maksudnya, seandainya Allah menuruti apa yang menjadi keinginan hawa nafsu mereka, lalu dia menetapkan suatu hal sesuai hal tersebut, niscaya langit dan bumi serta segala yang ada diantara keduanya akan hancur binasa. Yakni, karena rusak dan beragamnya keinginan mereka. ${ }^{74}$ Dalam

${ }^{73}$ KRH. Hadjid, Pelajaran KHA Dahlan (Jogjakarta: Majelis Pustaka dan Informasi Pimpinan Pusat Muhammadiyah, 2013), h. 64.

${ }^{74}$ Abdullah bin Muhammad bin Abdurrahman bin Ishaq Alu Syaikh, Tafsir Ibn Katsir, jilid 6 (Jakarta: Pustaka Imam al-Syafi'i, 2009), h. 228-229. 
kitab tafsir al-Qurtubhi juga dijelaskan maksud dari hawa nafsu pada ayat di atas adalah sebuah majaz. Maksud dari hawa nafsu di sini adalah mereka mengingkari para rasul dan maksiat kepada Allah. ${ }^{75}$

Dalam tafsiran itu mendapatkan analisis bahwa sebuah kebenaran yang tetap dan mutlak adalah hak Allah. Manusia diingatkan agar tidak asal-asalan dalam menetapkan sebuah ketetapan. Allah telah menurunkan Al-Qur'an untuk menjadi petunjuk. Tetapi kebanyakan manusia berbangga dan menuruti sesuai hawa nafsunya. Sehingga atas perbuatan tersebut menjadikan langit dan bumi rusak.

2. Surah al-Naml [27]: 34

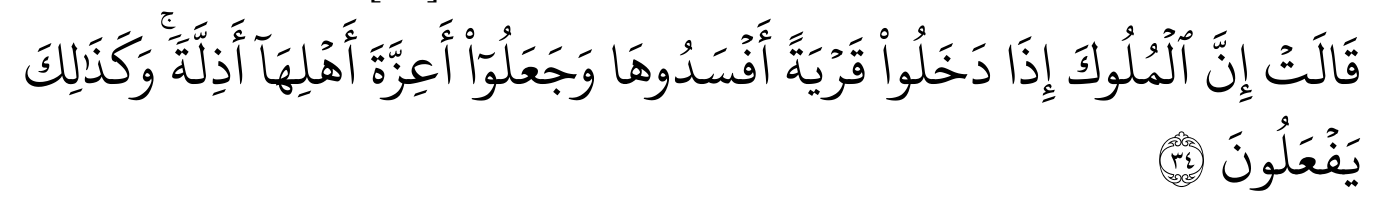

"Dia (Balqis) berkata, "Sesungguhnya raja-raja apabila me-nakhlukkan suatu negeri, mereka tentu membinasakannya, dan menjadikan penduduknya yang mulia jadi hina; dan demikian yang akan mereka perbuat." (QS. al-Naml [27]:

34)

Ibn Abbas berkata: "Yaitu apabila mereka memasuki suatu negeri untuk mengadakan peperangan, niscaya mereka menghancurkannya, yaitu membinasakannya." Mereka mengincar para pembesar dan tentara untuk dihinakan serendah-rendahnya, baik dengan membunuhnya ataupun menawan-nya. ${ }^{76}$

Ayat ini berkenaan dengan perilaku buruk yang dilakukan para pembesar yang dalam suatu negeri. Kata ifsad di sini merupakan sebuah kedzaliman. Mereka merusak apa saja yang ada (benda ataupun manusia) baik merusak dengan cara membakar, merobohkan, dan menghilangkan kemuliaan manusia. ${ }^{77}$

\section{Kerusakan Akibat Prilaku Merusak Lingkungan}

Lingkungan merupakan tempat manusia hidup, tempat manusia bekerja, dan tempat manusia beristirahat. Juga, lingkungan merupakan segala sesuatu di sekitar manusia, baik hewan, tumbuhan, dan benda-benda yang tak bernyawa. ${ }^{78}$ Sebab lingkungan merupakan lingkup yang tidak terpisahkan oleh manusia, maka manusia diberikan pilihan untuk "Melestarikan lingkungan" atau "Merusak lingkungan".

Namun, pada saat ini lingkungan telah mengalami perubahan. Perubahan itu dapat berupa pencemaran yang terjadi di berbagai tempat. Kecenderungan perubahan itu berupa pencemaran pada dua hal, yaitu: a). Pencemaran yang diakibatkan karena pembuangan senyawa-senyawa kimia $b$ ). Pencemaran yang diakibatkan penggunaan bahan berbahaya dan beracun oleh berbagai industri. ${ }^{79}$

Pencemaran merupakan kerusakan yang dilakukan oleh perbuatan manusia. Seperti

${ }^{75}$ Syaikh Imam al-Qurtubhi, Tafsir al-Qurtubhi, terj. Ahmad Khotib (Jakarta: Pustaka Azzam, 2008), h. 360-361.

${ }^{76}$ Imaduddin Abu al-Fida Ismail bin Katsir al-Qurays al-Dimasqy, Tafsir al-Qur'ān al-Adzīm, jilid 3 (Riyadh: Dar al-Salam, 1994), h. 482.

77 Departemen Agama RI, Pelestarian Lingkungan Hidup (Jakarta: Lajnah Pentashihan alQur'an, 2009), h. 213.

${ }^{78}$ Abuddin Nata, Akhlaq Tasawuf (Jakarta: PT Raja Grafindo Persada, 2008), h. 152.

${ }^{79}$ Rukaesih Achmad, Kimia Lingkungan (Jogjakarta: Andi Offset, 2004), h. 1. 
yang terdapat di dalam surat al-Rūm [30] : 41-42 berikut:

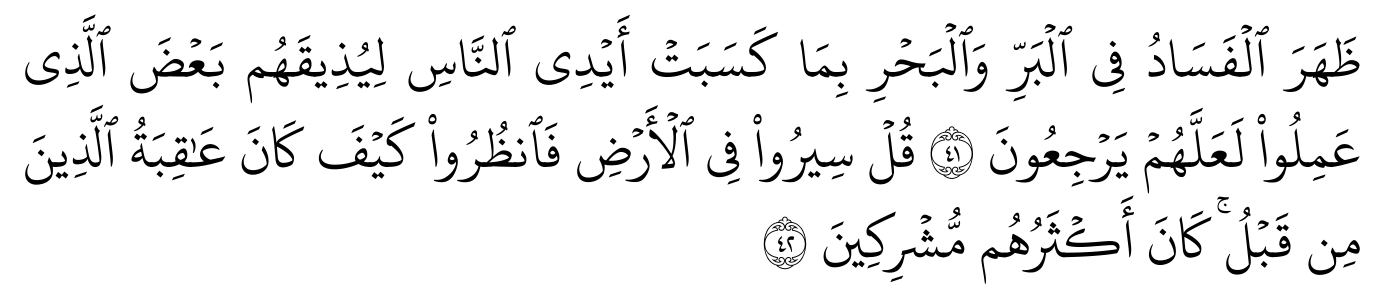

"Telah nampak kerusakan di darat dan di laut disebabkan karena perbuatan tangan manusia, supaya Allah merasakan kepada mereka sebagian dari (akibat) perbuatan mereka, agar mereka kembali (ke jalan yang benar). Katanlah: "Adakanlah perjalanan di muka bumi dan perhatikan bagaimana kesudahan orang-orang yang dahulu. Kebanyakan dari mereka itu orang-orang yang mempersekutukan (Allah)." (QS. al-Rūm [30] : 41-42)

Di dalam Tafsir Ibn Katsir, Ibn 'Abbas, 'Ikrimah, al-Dhahhak, al-Suddi berkata: "Yang dimakasud dengan al-Barr di sini adalah hamparan padang yang luas. Dan, yang dimaksud dengan al-Bahr di sini adalah kota-kota dan kampung-kampung. Dan disebutkan pula dalam tafsir ini, "ulama lain mengartikan keduanya dengan daratan dan lautan. Zaid bin Rafi' berkata: yang dimaksud dengan, "Telah nampak kerusakan," adalah terhentinya hujan di daratan diiringi dengan masa peceklik serta dari lautan, yaitu mengenai binatang-binatangnya. ${ }^{80}$ (HR. Ibnu Abi Hatim)

Dari penjelasan di atas dapat disimpulkan bahwa telah terlihat jelas perbuatan maksiat di daratan dan di lautan akibat perbuatan manusia yang melarang perintah Allah. ${ }^{81}$ Kerusakan yang menyebabkan terhentinya hujan di daratan dan diiringi peceklik bukanlah kerusakan yang tiba-tiba, melainkan sebab kemaksiatan perbuatan manusia kepada Allah. Melalaikan apa yang menjadi perintah Allah dan apa yang menjadi larangan Allah. Sehingga menjadi perhatian dan pengingat bahwa, perbuatan yang me-ngandung kemaksiatan akan menyebabkan kerusakan dan me-nyebabkan manusia kekurangan akan pangan untuk bertahan hidup. Seperti makna dari "Kerusakan" pada ayat di atas adalah kekurangan tanam-tanaman dan buah-buahan akibat dari kemaksiatan.

\section{PENUTUP}

Kerusakan hasil perbuatan manusia di muka bumi adalah sesuatu yang keluar dari keseimbangan. Keluarnya keseimbangan itu, berawal dari perbuatan manusia yang melakukan penyimpangan. Kerusakan hasil perbuatan manusia tidak hanya berfokus pada satu macam kerusakan, seperti kerusakan terhadap pencemaran lingkungan saja, melainkan mencakup berbagai macam kerusakan yang dilakukan oleh perbuatan manusia yang menyimpang. Dari sini dapat dipetakan bahwa, ragam kerusakan atas perbuatan manusia di muka bumi, yang keluar dari keseimbangan dapat dibagi menjadi 5 (lima) bagian, yaitu: 1) Kerusakan dalam bentuk penyimpangan akidah; 2) Kerusakan dalam bentuk kemaksiatan, 3) Kerusakan dalam bentuk tidak perduli terhadap orang yang lemah, 4) Kerusakan dalam bentuk memperturutkan hawa nafsu, dan, 5) Kerusakan dalam bentuk merusak lingkungan.

\footnotetext{
${ }^{80}$ Abdullah bin Muhammad bin Abdurrahman bin Ishaq Alu Syaikh, Tafsir Ibn Katsir, jilid 7 (Jakarta: Pustaka Imam al-Syafi'i, 2009), h. 183-184.

${ }^{81}$ Abu Ja'far Muhammad bin Jarir al-Thabari, Tafsir al-Thabāri, terj. Ahsan Sakan (Jakarta: Pustaka Azzam, 2009), h. 681.
} 


\section{DAFTAR PUSTAKA}

Achmad, Rukaesih. Kimia Lingkungan. Jogjakarta: Andi Offset, 2004.

Adzim, Sa'id Abdil. Berimanlah Sejenak Pasti Anda Selamat. Jakarta: Kalam Mulia, 2006.

Ali, Abdullah Yusuf. Tafsir Yusuf Ali. Bogor: Pustaka Litera Antar Nusa, 2009.

Aman, Saifuddin. Tren Spiritual Millenium Ketiga. Jakarta: Ruhama, 2013.

Amalia, Efa Ida. “Kehancuran Alam Semesta dalam Al-Qur'an.” Kajian Al-Qur'an dan Kebudayaan, vol. 2, no. 1, (2009): 74.

Anshori. Ulumul Qur'an: Kaidah-kaidah Memahami Firman Tuhan. Jakarta: Rajawali Press, 2016.

Ardani, Moh. Ahklaq-Tasawuf. Penerbit: CV. Karya Mulia, 2005.

Ash Shiddieqy, Muhammad Hasbi. al-Bayan Tafsir Penjelas al Qur'anul Karim. Semarang: Pustaka Rizki Putra, 2002.

Asmaran. Pengantar Studi Akhlak. Jakarta: PT Raja Grafindo Persada, 1994.

al-Asfahani, Abu Qosim al-Husain bin Muhammad. al-Mufradāt fì Gharīb Al-Qur'ān. Beirut: Dar al-Ma'rifah, 2002.

Buchori, Didin Saefuddin. Metodologi Studi Islam. Tangerang: Serat Alam Media, 2012.

Dahlan, Abd Rahman. Kaidah-kaidah Penafsiran Al-Qur'an. Bandung: Penerbit Mizan, 1998.

Departemen Agama RI. Pelestarian Lingkungan Hidup. Jakarta: Lajnah Pentashihan AlQur'an, 2009.

Departemen Pendidikan Nasional. Kamus Besar Bahasa Indonesia (KBBI), Jakarta: PT Gramedia Pustaka Utama, 2008.

Echols, John M. dan Hassan Shadily. Kamus Inggris-Indonesia. Jakarta: PT. Gramedia Pustaka Utama, 2010.

Enoh. "Konsep Baik (Kebaikan) dan Buruk (Keburukan) dalam Al-Qur'an.” Vol. 23 No. 1 (Januari - Maret 2007).

Furchan, Arief. Pengantar Metode Penelitian Kuantitatif. Surabaya: Usaha Nasional, 1992.

Hadjid. KRH. Pelajaran KHA Dahlan. Jogjakarta: Majelis Pustaka dan Informasi Pimpinan Pusat Muhammadiyah, 2013.

Harahap, Syahrin. dan Hasan Bakti Nasution. Ensiklopedia Akidah Islam. Jakarta: Kencana, 2009.

Hasyimi, Muhammad Ali. Apakah Anda Berkepribadian Muslim?. Jakarta: Gema Insani Press, 1994.

Ibn Katsir. al-Bidāyah wa al Nihayāh, terj. Abdullah bin Abdul Muhsin al-Turki. Jakarta: Pustaka Azzam, 2013.

Imani, Allamah Kamal Faqih. Tafsir Nurul Qur'an. Jakarta: al Huda, 2003.

Ismail, Imaduddin Abu al-Fida. Tafsir Al-Qur'ān al-Adzìm. Riyadh: Dar al Salam, 1994. 
Izzan, Ahmad. Metodologi Ilmu Tafsir. Bandung: Tafakur, 2011.

Iswanto, Agus. "Relasi Manusia dengan Lingkungan dalam al- Qur'an.” Suhuf, vol. 6, no. $1,2013$.

Izutsu, Toshihiko. Etika Beragama dalam Al-Qur'an,Jakarta: Pustaka Firdaus, 1993.

Ilyas, Yunahar. Kuliah Akhlaq. Jogjakarta: Lembaga Pengkajian dan Pengamalan Islam (LPPI), 2001.

Ismail, Imaduddin Abu al-Fida. Tafsir Juz 'Amma. Jakarta: Pustaka Azzam, 2007.

Jazuli, Ahzami Samiun. Kehidupan dalam Pandangan al- Qur'an. Jakarta: Gema Insani, 2006.

al-Jazairi, Abu Bakar Jabir. Tafsir Al-Qur'an al-Aisar. Jakarta: Darus Sunnah, 2015.

Katsir, Ibn. al-Bidāyah wa al-Nihāyah. Jakarta: Pustaka Azzam, 2013.

Keraf, Sonny A. Etika Lingkungan Hidup. Jakarta: PT Kompas Media Nusantara, 2010.

al-Mahalli, Jalaluddin dan Jalaluddin al-Suyuthi. Tafsir Jalalain. Bandung: Sinar Baru Algensindo, 2009.

Machmud, Syahrul. Penegakan Hukum Lingkungan Indonesia. Jogjakarta: Graha Ilmu, 2012.

Mahmud, Ali Abdul Halim. Akhlaq Mulia. Jakarta: Gema Insani Press, 2004.

Maliki. "Tafsir Ibn Katsir: Metode dan Bentuk Pemikirannya." el-Umdah, vol. 1, no. 1 (2018).

Mardan, Abd Muin Salim dan Achmad Abu Bakar. Metodologi Penelitian Tafsir Maudu'i. Jogjakarta: Pustaka al-Zikra, 2017.

Muhammad, Abu Ja'far. Tafsir al-Thabari. Jakarta: Pustaka Azzam, 2009.

Munawwir, Ahmad Warson. Kamus al-Munawwir Arab Indonesia. Surabaya: Pustaka Progressif, 1997.

Nata, Abuddin. Akhlaq Tasawuf dan Karakter Mulia Jakarta: Rajawali Pers, 2015.

Al-Qaththan, Manna. Penga ntar Studi Ilmu Al-Qur'an. Jakarta: Pustaka al-Kautsar, 2005.

Al-Qurtubhi. Tafsir al-Qurtubhi. Jakarta: Pustaka Azzam, 2008.

R.A. Haqqi, Abdurrahman dan Mohammad Nabil Munawwar. Tafsir Zanjabil. Jakarata: Qisthi Press, 2015.

Sani, Ridw'an Abdullah. Sains Berbasis Al-Qur'an. Jakarta: PT Bumi Aksara, 2015.

Salam, Burhanuddin. Etika Individual. Jakarta: PT. Rineka Cipta, 2000.

Saryono. "Konsep Fitrah dalam Persfektif Islam.” Studi Islam vol. 4, no. 2 (Desember 2016).

Sirajuddin, Iqbal Mashruri dan Fudlali. Pengantar Ilmu Tafsir. Bandung: Percetakan Angkasa, 2009.

Sofyan, Muhammad. Tafsir wa al-Mufassirun. Medan: Perdana Publishing, 2015.

Sukidi. Teologi Inklusif Cak Nun. Jakarta: Kompas, 2001. 
Sugiyono. Metode Penelitian Kuantitatai, kualitatif dan $R$ dan D. Bandung: Alfabeta, 2007.

Imam Sudarmoko. “Keburukan dalam Persfektif Al-Qur'an.” Dialogia, v.12, no. 1 (Juni 2014).

Shihab, Muhammad Quraish. WawasanAl-Qur'an. Bandung: Mizan Pustaka, 2013.

Shihab, M. Quraish. Tafsir al-Misbah. Tangerang: Lentera Hati, 2000.

Wardhana, Wisnu Arya. Dampak Pencemaran Lingkungan Yogyakarta: Andi Offset, 2004.

Zuriah, Nuzul. Metodologi Penelitian. Jakarta: PT Bumi Aksara, 2009. 